\title{
La iconología del toro en la moneda provincial acuñada bajo el gobierno de Tiberio en el valle interior del Ebro
}

The diffusion of the bull's image in the Tiberian provincial coin of the middle valley of Ebro

\section{Helena Gozalbes}

Becaria de investigación doctoral.

Resumen: El presente trabajo pretende estudiar el fenómeno de difusión de la imagen del toro en la moneda provincial acuñada durante el imperio de Tiberio en el valle del Ebro. Para ello, presentamos un detallado análisis acerca de los aspectos materiales e iconográficos relacionados con la imagen monetaria, intentando determinar su posible actuación dentro de un proceso de proyección emblemática en la zona.

Palabras Clave: Numismática; Iconografía; Iconología; imperio de Tiberio; valle del Ebro; Identidad romana.

\begin{abstract}
This paper intends to approach a study about the phenomenon of diffusion of the bull's image in the provincial coinage fabricated during the period of government of Tiberius in the Ebro valley region. To achieve this objective we present a detailed analysis about the material and iconographic aspects of the image, attempting to determinate its operation within a process of emblematic propaganda in the area.
\end{abstract}

Keywords: Numismatic; Iconography; Iconology; Tiberius; Ebro valley; Roman identity.

\section{INTRODUCCIÓN}

- L análisis de la imagen del toro en la moneda provincial hispana ha sido objeto de numerosos estudios centrados sobre todo en intentar interpretar cuál pudo ser el simbolismo particular relacionado con esta representación. M. Grant, que fue uno de los primeros autores que trató de analizar de manera definida y deliberada 
su significado, precisó que aquella representación debía identificarse como un tipo parlante referente al assignator de algunas de las ciudades que según la propia interpretación del autor la habían empezado a divulgar en su monetario (Lepida-Celsa, Calagurris y Carthago-Nova), el gobernador de Hispania, T. Estatilo Tauro (Grant, 1946: 165 y 211-212). Algún tiempo después, aparecieron diversas investigaciones que plantearon interpretaciones distintas, las cuales, en contraste con la anterior, han sido habitualmente asumidas en la bibliografía posterior. Entre estos trabajos se encuentra la célebre aportación de G. López Monteagudo, en la que la autora propuso que el icono podría haber tenido un sentido puramente religioso (López Monteagudo, 19731974: 233-247). Frente a esta hipótesis, otros historiadores como J. Mª Blázquez y Mª . P. García-Gelabert, remitieron a la riqueza ganadera de la zona, para apuntar que el mensaje de la imagen también podía vincularse con una alusión de naturaleza en parte económica (Blázquez, 1962: 27; García-Gelabert, Blázquez, 1997: 423).

Esta controversia que giraba en torno a determinar el posible simbolismo específico del icono (ya se vinculase con un programa iconográfico o con otro) puede observarse también de forma acentuada en la bibliografía más actual. Así, podemos mencionar, de un lado, investigaciones generales como las de F. Chaves, M. C. Martín, M. Gozalbes Fernández de Palencia y P. P. Ripollès (Chaves, 1998: 85; Chaves, Martín, 1993: 667; Gozalbes Fernández de Palencia, 2006: 124; Ripollès, 1997a: 380; 2005: 201; 2010: 27), y otras centradas en el estudio monográfico de cecas concretas. Entre estas últimas, se encuentra la monografía de M. Gomis sobre la ciudad emisora de Ercavica (Gomis 1997a: 28-33), la de M. Ruiz Trapero sobre el centro de Calagurris (Ruiz Trapero 1968: 55) o los más recientes de A. Aguilera y M. Gómez Barreiro sobre la colonia de Caesaraugusta (Aguilera, 2017; Gómez Barreiro, 2008: 108; 2017: 149-150). Casi la totalidad de estas aportaciones han asumido de manera específica la explicación cívico-religiosa. Consideramos que esta hipótesis se ha expuesto de manera bastante argumentada, dado que, como recuerda T. Hurtado, en algunos casos el adorno que presentaba la figura del animal así podría evidenciarlo (RPC I, 327-328, 334-337, 340, 367, 462 y 465-466) (Hurtado, 2013: 131).

En cambio, otras contribuciones, como las publicadas por L. Amela, M. Beltrán Lloris, A. Mostalac, J. A. Lasheras, J. Á. Paz Peralta y T. Hurtado, han planteado una interpretación parcialmente distinta. Estos autores defienden que la introducción de la imagen del toro en la ceca triunviral de Lepida debió responder a una propaganda religioso-militar y cívica relacionada con la re-fundación colonial de la propia ciudad (Amela, 2018: 175; Beltrán Lloris, Mostalac, Lasheras, 1984: 15-16; Beltrán Lloris, Paz Peralta, 2014: 16-19; Hurtado, 2006: 92-93; 2013: 130-132). En caso de que se asuma esta suposición podría proponerse la posibilidad de que a partir de entonces aquella iconología comenzase a hacer referencia a un mensaje alusivo a las ceremonias celebradas en el contexto de promoción colonial y/o municipal de otras ciudades ubicadas en el territorio en el que empezaron a divulgarse aquellas imágenes monetarias.

Nosotros consideramos que esta es la interpretación más verosímil de todas las planteadas hasta la fecha, puesto que además somos de la opinión de que se 
ha formulado de un modo muy argumentado y así lo hemos defendido en algún trabajo anterior (Gozalbes García, 2019: 37-50). No obstante, del mismo modo, creemos oportuno advertir que no puede descartarse rotundamente que el icono se hubiera vinculado también con un mensaje de alusión económica, ya que no dejaba de ser la representación de un animal de vital importancia para la subsistencia del territorio y, por tanto, de usual visualización en los pastos y ganaderías de aquella zona (Gozalbes García, 2014: 142).

Sea como fuere, el objetivo del presente trabajo no es analizar el posible simbolismo particular del que dispuso la imagen del toro, pues, como se ha detallado, sobre este asunto ya se han publicado importantes contribuciones que han tratado el tema de modo, en nuestra opinión, lo suficientemente conveniente y razonado. Además, resulta bastante indudable que pasado el tiempo los amplios y prolongados fenómenos de copia de la representación en las emisiones de la región debieron afectar de manera muy notable a su posible significado original. En este contexto, su simbología pudo comenzar a relacionarse con una nueva proyección, que seguramente sin olvidar del todo la anterior, estuvo quizá más vinculada a la emblemática regional de la zona, es decir a la ideología relacionada con la entidad del territorio y sus habitantes.

En nuestra opinión, el significado particular del icono (ya fuese religioso, económico, militar y/o político) fue un incidente cuya trascendencia fue atenuándose progresivamente en la mayoría de centros que acuñaron ejemplares en época imperial, dado que en una gran parte de las monedas el simbolismo de la imagen fue escasamente manifiesto. Quizá resultó de mayor interés copiar la representación ya que esta resultaba de fácil visualización y asimilación por parte de los posibles usuarios de aquellas piezas.

Estas ideas, que creemos especialmente irrefutables por lo que respecta a la interpretación relativa a la mayoría de ejemplares acuñados durante el imperio de Tiberio (pero que, como veremos no puede aplicarse a la totalidad de piezas fabricadas), parten de las tesis ya propuestas en su día por M. Gomis y F. Beltrán (Beltrán Lloris, 2002: 174; Gomis, 1997b: 21). Sin embargo, frente a estos supuestos interpretativos, determinados trabajos, como los publicados recientemente por A. Aguilera, han optado por defender que la verificación de las diversas variaciones iconográficas relacionadas con la iconología del toro es una cuestión especialmente determinante que evidencia la posibilidad de que se pudieran desarrollar particularidades en lo referente al simbolismo de las distintas representaciones (Aguilera, 2015: 538; 2017: 126).

Con todo, como se detallará en posteriores puntos, algunas cecas prefirieron adoptar la imagen de un toro de pie sin ornamentos (en la mayor parte de los casos en actitud tranquila [RPC I, 262-263, 265, 269-273, 278-279, 417-419, 425-428, 431, 433441, 444-448, 450, 452, 454, 456-457, 459-460 y 468; RPC S-451A-C] y, en algunos ejemplares embistiendo [RPC I, 264a] o saltando [RPC I, 264b], mientras que otras optaron por vincularse con la representación de un toro de pie mitrado [RPC I, 327-328, 334-337, 340, 367, 429, 462 y 465-466]. Además, algunas de estas ciudades decidieron también incluir la figura de la cabeza de un bóvido [RPC I, 430, 432, 442 y 451]). 
En el presente trabajo hemos intentado tener en cuenta y profundizar sobre todas estas propuestas teórico-metodológicas presentando un estudio acerca del fenómeno de difusión ideológica de la imagen del toro en las emisiones tiberianas fabricadas por las cecas del valle interior del Ebro. Intentaremos determinar si esta imagen se divulgó como parte de una proyección de tipo fundamentalmente emblemáticoregional, como parecen sugerir los datos generales o, si fue, en cambio, coherente con una narración mucho más extensa y particular de cada ceca, en la que su posible alusión religioso-cívica tuviera una mayor significación.

Para lograr nuestros objetivos, en una primera parte, exponemos una valoración acerca de las cecas que adoptaron este icono; en estos párrafos los datos serán tenidos en consideración sin tener en cuenta las distintas imágenes relacionadas con esta iconología, pues, como se intentará detallar, creemos bastante probable que los usuarios (y seguramente los propios comitentes) de estas monedas terminaran vinculando de manera general unas producciones y otras. En una segunda parte del trabajo, presentamos un estudio sobre los elementos iconográficos relacionados con esta iconología monetaria en la época objeto de análisis, atendiendo en estos párrafos a las diferencias representativas de las distintas imágenes divulgadas. En la tercera parte, recogemos un análisis acerca de los distintas propuestas de divulgación de la representación, en relación sobre todo al volumen de emisión de cada ceca y las denominaciones en las que este icono se decidió adoptar.

\section{LOS CENTROS EMISORES DEL VALLE DEL EBRO QUE DIVULGARON LA ICONOLOGÍA MONETARIA DEL TORO}

La primera ceca provincial situada en la región del valle del Ebro que adoptó la imagen del toro como tipología monetaria fue la colonia Lepida-Celsa (Velilla del Ebro, Zaragoza) (RPC I, 262-265). Fue, por tanto, este el lugar donde debió introducirse esta especial propuesta iconológica (Gozalbes García, 2019: 32). La ciudad de Lepida-Celsa se encontraba situada en el valle oriental del río Ebro. Había sido refundada en época triunviral con un régimen jurídico colonial. Poco tiempo después, tras una primera acuñación en la que se adoptó la representación de un colono arando con yunta de bueyes (RPC I, 261), la colonia empezó a acuñar monedas divulgando la iconología del toro como tipología principal de reverso. La mayor parte de autores proponen que estas emisiones fueron series posiblemente batidas tras la muerte de Julio César (44 a. C.) (Amela, 2000: 7-33; 2001-2002: 149-159; 2004: 207-217; 2012a: 31-52; 2018: 171; Beltrán Lloris, 2017: 528; Beltrán Lloris, Mostalac, 2008: 108-109; Beltrán Lloris, Mostalac, Lasheras, 1984: 19; Burnett, Amandry, Ripollès, 1992: 111-112; Grant, 1946: 1946; Hernández Guerra, 2006b: 241; Ripollès, 1997b: 32; 2010: 185-187; Ripollès, Abascal, 2000: 338-339; Sayas, 1996: 78; Villaronga, 1994: 224; Villaronga, Benages, 2011: 275), si bien algunas otras especialistas han planteado la posibilidad de que la cronología de emisión de estas piezas pudiera adelantarse a los momentos de guerra civil entre el mencionado político y Cneo Pompeyo (Blázquez Cerrato, 2008: 266; García-Bellido, 2003: 278-279; 2004: 96 y 98; 2006a: 684; García-Bellido, Blázquez Cerrato, 2001: 237). 
Durante los años del Principado fueron 4 las cecas situadas en esta región del valle interior del Ebro ${ }^{1}$ que acuñaron moneda adoptando la iconología del toro como tipología monetaria. Entre ellas, nuevamente la colonia Lepida-Celsa (RPC I, 270-273 y 278). En segundo lugar, el municipio de Calagurris (Calahorra, La Rioja). Esta ciudad se encontraba ubicada en una zona algo alejada del resto de cecas augusteas de la región, pues se localizaba en la ribera occidental del río. Calagurris fue favorecida con un régimen jurídico municipal de derecho romano (Beltrán Lloris, 2017: 526) seguramente en los primeros instantes del periodo augusteo.

Fue durante aquellos años cuando la ceca debió reiniciar la actividad de fabricación de moneda de su taller, seguramente en los primeros instantes de la etapa augustea (Abascal, Alberola, Cebrián, 2008: 61; Amela, 2012b: 141; 2018: 136-137; Andrés Hurtado, 2002: 69; Beltrán Lloris, 2017: 531; Beltrán Lloris, Beltrán Lloris, 1980: 62; Blázquez Cerrato, 2008: 270; Burnett, Amandry, Ripollès, 1992: 135-136; Espinosa, 1984: 75-77; 2011: 89-90; García-Bellido, Blázquez Cerrato, 1995; Gozalbes García, 2019: 32-33; Grant, 1946: 165; Llorens Forcada, 2005: 123; Ripollès, 1997b: 33; 2010: 135; Ripollès, Abascal, 2000: 411). Sin embargo, algunos autores han planteado la posibilidad de que las primeras series provinciales calagurritanas (RPC I, 431-432) fueron puestas en uso en época triunviral (Beltrán Lloris, 1978: 203-204; Beltrán Martínez, 1984; 53-66; Beltrán Villagrasa, 1972: 170-173; Medrano Marqués, Díez Sanz, 1985-1986: 163; Ruiz Trapero, 1968: 80 y 94; Solana, 1989: 90; Villaronga, 2004: 244; Villaronga, Benages, 2011: 582-583).

En cualquier caso, estas primeras series acuñadas por orden de Calagurris ya atestiguan la adopción del icono del toro como tipo de reverso (RPC I, 431-442 y 444447). A tenor de este asunto, resulta de interés mencionar que hasta la fecha se han atestiguado 3 emisiones distintas de posibles monedas «hibridas» (RPC S- 451A-C) con cuños de anverso calagurritanos (RPC I, 433 y 436) (fechados durante el periodo del Principado) e impresiones de reverso lepidano-celsanas (RPC I, 262 y 269) (fechadas en época triunviral). Tal y como advierte algún autor, es bastante probable que estos especiales ejemplares se relacionen con producciones fraudulentas elaboradas en algún lugar indeterminado en una fecha cercana a la década de los años 20 a. C. (Ripollès, 2010: 271). Con todo, los distintos cuños utilizados para la fabricación de estas monedas han sido datados en momentos diversos y en todos los casos se relacionan con punzones de mala calidad o con instrumentos muy desgastados.

No obstante, pese a ello, tampoco podemos descartar que estas series fueran resultado de un proceso erróneo desarrollado en el marco de una efectiva cooperación entre ambas ciudades (Rodewald, 1976: 131; Villaronga, 1969: 21-22) o que fueran el producto desperfecto del trabajo de un mismo taller que operara para los dos centros (García-Bellido, 2006b: 236). Así pues, pese a que, atendiendo a los datos de los que

\footnotetext{
1 Además, durante este periodo las cecas hispanas de Tarraco y Carthago-Nova también acuñaron ejemplares divulgando aquella tipología de reverso (RPC I, 158, 211-214 y 216-217).
} 
actualmente se dispone, estas dos últimas hipótesis no pueden plantearse de modo totalmente seguro, resultan de enorme interés, pues de ser consideradas como posibles podrían contribuir a profundizar en las causas que expliquen la temprana adopción del icono del toro en las producciones de un municipio tan alejado de LepidaCelsa como era Calagurris.

Sin embargo, este posible planteamiento basado en el estudio de monedas catalogadas como «híbridas» no puede relacionarse con la producción del resto de centros. Entre ellos el vinculado con el municipio de Ercavica (Cañaveruelas, Cuenca), que fue precisamente la tercera ceca situada en este entorno que seleccionó la iconología del toro en el monetario que emitió durante el Principado (RPC I, 459-461). Esta ciudad recibió el status de civitas privilegiada en los años de gobierno de Augusto (Alföldy, 1987: 66-74; Ripollès, 1997b: 33; 2010: 278; Rubio Ribera, 2004: 218; 2013: 175-176); momentos en los que hubo de reiniciar su actividad de producción de moneda, introduciendo el icono del toro seguramente en una fecha cercana al cambio de Era.

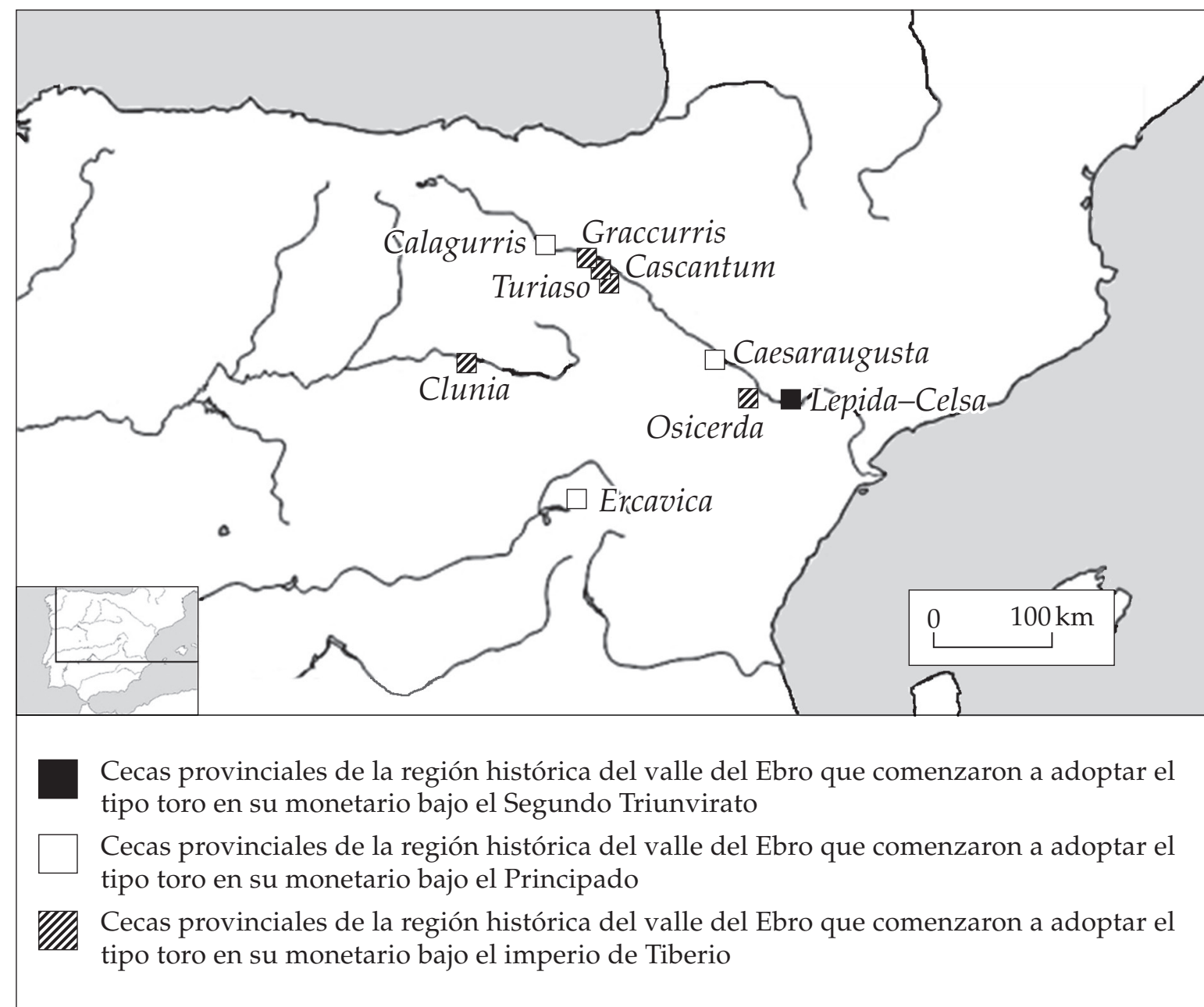

Figura 1

Localización de las cecas provinciales hispanas que emitieron monetario con el tipo toro en su reverso, según periodo de inicio de acuñación de la serie monetaria con dicha iconografía 
El municipio de Ercavica estaba situado en una zona bastante alejada del eje principal de la propia ribera del Ebro, en territorio en dirección sureste en relación a la misma. No obstante, pese a la relativa lejanía territorial del centro con respecto al propio río y las ciudades emisoras de sus alrededores, esta ciudad ha sido generalmente incluida entre las cecas de la región interior del valle del Ebro (Beltrán Lloris, 2017: 526). Debe tenerse en cuenta que las influencias culturales y, más en concreto, las propiamente monetarias que se revelaron en el núcleo desde época anterior fueron particularmente visibles y, en consecuencia, puede argumentarse la propuesta interpretativa que relaciona este municipio con las cecas ubicadas en las inmediaciones de la ribera interior del Ebro.

Finalmente, la cuarta ciudad emisora ubicada en estos territorios que adoptó la iconología del toro como tipología monetaria en época del Principado fue la colonia de Caesaraugusta (Zaragoza, Zaragoza) (RPC I, 327-328). Esta ciudad se encontraba localizada en el valle oriental del río, a escasos kilómetros de la ya mencionada ceca de Lepida-Celsa. Caesaraugusta fue al igual que aquella re-fundada como colonia, en este caso, precisamente durante el periodo augusteo (Aguilera, 2014: 95-129 y 462-467; 2017: 43; Domínguez, Aguilera, 2009: 455-472; 2011-2012: 63-84; 2012: 72-77; Gómez Barreiro, 2003: 292-295; 2017: 101-104; Gómez-Pantoja, 1994: 169-175); momentos en los que, como algunos otras ciudades cercanas, comenzó a emitir moneda provincial, adoptando la imagen del toro como tipología monetaria. Es bastante probable que estas emisiones se fabricaran una vez que las lepidano-celsanas, calagurritas y ercavicenses ya se encontrasen en la masa disponible para su uso en la zona, pues según la cronología planteada recientemente por A. Aguilera fueron fabricadas en torno al año 7 d. C. (Aguilera, 2017: 60, 252 y 256).

Por tanto, durante aquellos años iniciales del periodo imperial romano la iconología monetaria del toro no fue adoptada de manera totalmente generalizada en las piezas monetarias fabricadas por los centros emisores dispersados por la región que se analiza. De las 9 cecas que en aquellos años pudieron estar en actividad en los terrenos de la ribera del Ebro y sus inmediaciones (es decir Ilerda, Lepida-Celsa, Osca, Caesaraugusta, Bilbilis, Turiaso, Calagurris, Ercavica y Segobriga), sólo 4 acuñaron series adoptando esta imagen. Fue, precisamente, durante los años de gobierno de Tiberio el periodo en el que se produjo el mayor auge en la divulgación del icono del toro en el monetario puesto en circulación por las diversas ciudades de esta región. Considerando los datos de producción hasta la fecha conocidos, puede observarse cómo durante aquellas décadas esta iconología fue adoptada de manera casi generalizada en las acuñaciones de la mayor parte de ciudades emisoras ubicadas en este entorno. De hecho, de las 12 cecas localizadas en la región y sus cercanías que en aquellos momentos pudieron fabricar ejemplares (esto es Lepida-Celsa, Osca, Caesaraugusta, Bilbilis, Turiaso, Cascantum, Graccurris, Calagurris, Clunia, Ercavica, Osicerda y Segobriga), 9 emitieron moneda divulgando esta imagen como tipología de reverso.

Estas 9 ciudades no solo se localizaban en los límites del conventus Caesaraugustanus, como había ocurrido en época anterior, sino que uno de aquellos centros estaba incluido en otra administración territorial, el conventus Cluniensis. El protagonismo de 
las cecas que acuñaron piezas con esta iconología en ambas circunscripciones territoriales fue verdaderamente notable, pues de las 10 ciudades emisoras del conventus cuya capital era Caesaraugusta, 8 produjeron moneda con esta tipología y en el Cluniensis fue el único icono monetario que se decidió adoptar en las series de mayor fabricación y, por consiguiente, en los ejemplares de más probable utilización².

Sin embargo, aunque es evidente que la iconología monetaria del toro presentó una privativa relación con los conventii situados en el entorno interior del valle del Ebro, caracterizada por su generalización en las emisiones fabricadas por las distintas cecas, lo cierto es que la vinculación de aquel icono con la circunscripción caesaraugustana no fue completamente exclusiva. Con todo, hubo dos cecas incluidas en este conventus (en este caso, Osca y Bilbilis) cuyos magistrados decidieron que los centros que gobernaban se asociaran a otro tipo de representaciones de reverso (RPC I, 291-299 y 397-399).

Entre las 9 cecas que acuñaron moneda tiberiana adoptando el icono del toro se encontraban las ciudades emisoras que en época augustea ya habían batido algunos ejemplares divulgando aquella imagen. A estos 4 núcleos deben sumarse otras 5 cecas, asociadas todas ellas a centros municipales, cuyas oficinas monetarias en casi todos los casos se inauguraron o reabrieron precisamente durante los años inmediatamente posteriores a la etapa del Principado. De entre ellas, tan solo una se encontraba localizada en el territorio oriental del valle del Ebro, que fue precisamente la zona de mayor divulgación del icono en época augustea. Nos referimos al municipio de Osicerda. Esta ceca, seguramente estaba situada ${ }^{3}$ en el extremo más oriental de la región (Beltrán Lloris, 2004: 72), en una zona cercana a las colonias de Lepida-Celsa y Caesaraugusta.

La ciudad de Osicerda se promocionó como municipio latino (Beltrán Lloris, 2017: 526; Grant, 1950: 152-153) en una fecha, en la actualidad, bastante insegura. A la vista de las leyendas grabadas en las piezas hispanorromanas que este centro puso en circulación se puede deducir que en los años de imperio de Tiberio ya debió haber obtenido el estatuto municipal (Gomis, 1996: 29); si bien, tampoco puede descartarse que este núcleo hubiera sido promocionado como ciudad privilegiada en época anterior (Ripollès, 2010: 283). Como el resto de cecas de la región interior del valle del Ebro que comenzaron a acuñar ejemplares provinciales en época tiberiana, Osicerda batió piezas correspondientes a monedas de fábrica hispanorromana tan solo durante aquella etapa, clausurando su oficina poco tiempo después de su propia apertura.

\footnotetext{
2 Ahora bien, debe recordarse que en época de acuñación provincial tan sólo emitió moneda un centro ubicado en el territorio de este conventus.

3 Como recuerdan algunos autores, el emplazamiento exacto de esta ciudad sigue siendo motivo de cierta controversia historiográfica (Beltrán Lloris, 2004; García-Bellido y Blázquez Cerrato, 2001: 399; Ripollès, 2010: 283). Es cierto que la mayor parte de los investigadores apuestan por localizar el centro en la zona del bajo Ebro, pero en sitios arqueológicos dispersados en lugares distintos como Osera del Ebro (Zaragoza) (Beltrán Lloris, 1980: 14), Puebla de Híjar (Teruel) (Beltrán Lloris, 1996: 287-294; 2004: 77), La Caridad de Caminreal (Teruel) (Pérez Vilatela, 1990) o Alcañiz (Teruel) (Burillo, 2002: 1986).
} 


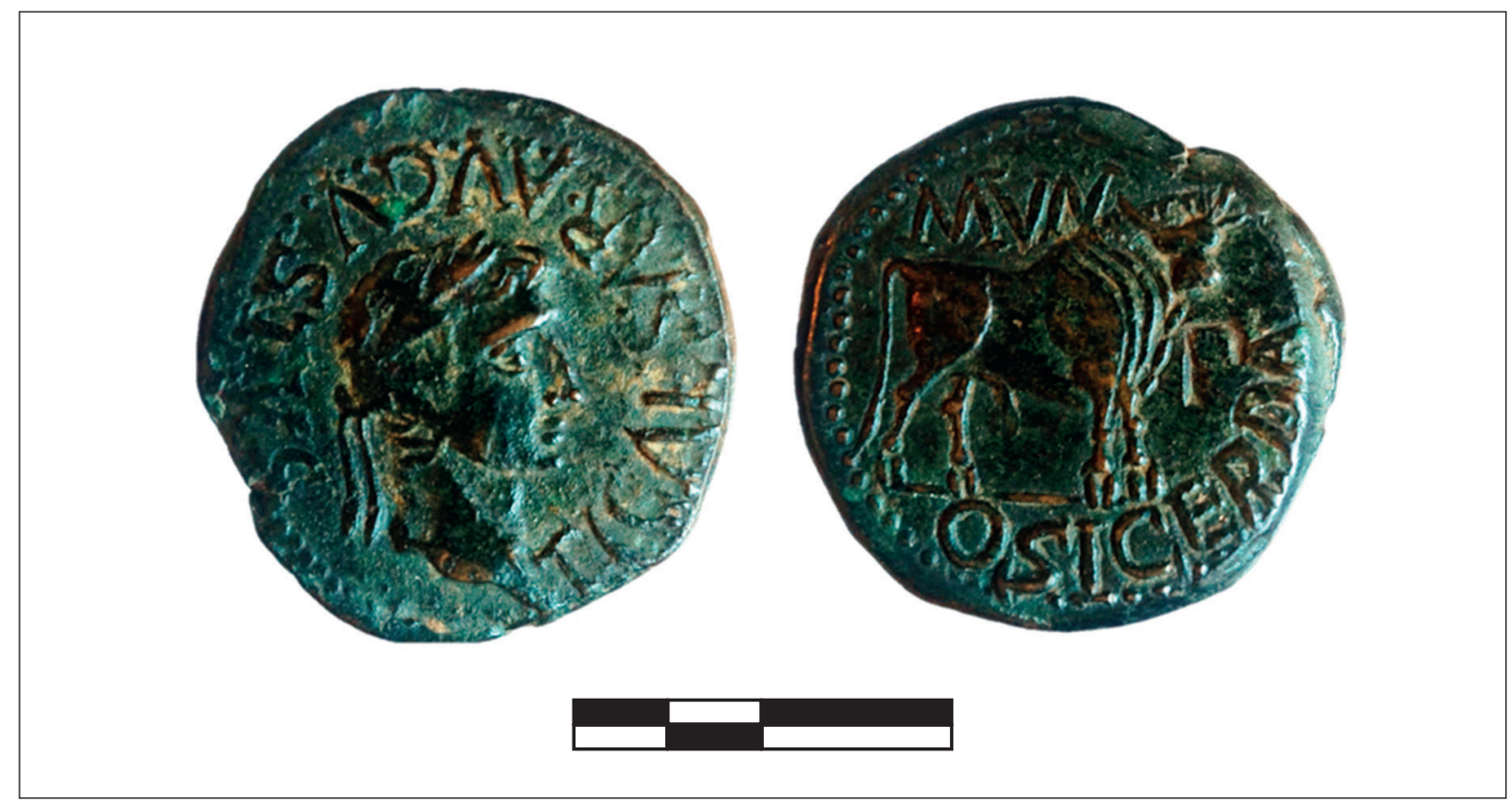

Figura 2

As acuñado en Osicerda bajo el imperio de Tiberio (RPC I, 468) (MAN 1993/67/12821)

Las 4 cecas restantes que comenzaron a batir series con la iconología taurina en época tiberiana se encontraban localizadas en el territorio de la ribera occidental del Ebro. A tenor de ello, podría ser interesante recordar que los ejemplares fabricados por estas ciudades occidentales han sido recientemente relacionados estilísticamente entre sí (Ripollès, 2010: 253 y 273). Sobre todo son evidentes las semejanzas que existen entre los retratos y leyendas de anverso de algunas de las monedas batidas por orden de estas cecas, especialmente de aquéllas que divulgaron la iconología del toro (RPC I, 417, 425$430,452,454$ y 456-457). Este aspecto similar advertido en lo referente a los elementos grabados en las caras principales de estas series monetarias podría ser resultado de un posible proceso de elaboración compartido (quizá un mismo grabador o taller) y, en todo caso, confirma la indudable relación entre la producción de estos 4 municipios.

Así ocurrió en lo correspondiente a las emisiones fabricadas por encargo de la ciudad de Cascantum (Cascante, Navarra); urbe situada en una zona muy próxima a Calagurris. Al igual que aquel centro, Cascantum fue promocionado con un status cívico municipal latino (Beltrán Lloris, 2004: 526) en un momento impreciso del periodo de gobierno de Augusto (Faria, 2007: 311; Hernández Guerra, 2006a: 220; Ripollès, 2010: 253). Sin embargo, en contraste con lo contemplado por lo que respecta a la política monetaria aprobada por los magistrados de la ciudad de Calagurris, la actividad de producción de monedas de Cascantum no se reinició hasta décadas después, coincidiendo ya con los años de imperio de Tiberio. De hecho, los datos de fabricación de ejemplares conocidos confirman que debió ser precisamente esta etapa inmediatamente posterior al Principado el único periodo en el que el centro acuñó piezas provinciales (RPC I, 425-428).

A escasos kilómetros de Cascantum se encontraba el municipio de Graccurris (Alfaro, La Rioja). Esta ciudad comenzó a fabricar moneda en bronce en un momento im- 
preciso del periodo de gobierno de Tiberio, adoptando, en este caso, también el icono del toro como tipología de reverso (RPC I, 429-430). Al igual que sus vecinas Calagurris y Cascantum, Graccurris se promocionó como civitas con un régimen jurídico privilegiado (en este caso de municipium latino [Beltrán Lloris, 2017: 526]) en algún momento de la extensa etapa de gobierno de Augusto (García-Bellido, Blázquez Cerrato, 2001: 155; Ripollès, 2010: 257). No obstante, a diferencia de lo que se advierte con respecto al resto de cecas provinciales de la región (CNH 41.32-36, 42.37-39, 43.4348, 44.49-53, 176.1-8, 177.9-16, 178.17-23, 179.24-31, 180.32-39, 181.40-48, 182.49-50, 184.1-2, 211.1-8, 212.9-15, 213.1, 222.1-8, 222.9-16, 224.17, 228.1-2, 229.3-4, 237.1, 238.2-8, 239.9.15, 258.1, 259.2-4, 262.1-3, 263.4-11, 264.12-19, 265.20-26, 266.27-33, $267.34,276.1-3,277.4,283.1-4$ y 287.1-2), este centro, presumiblemente conocido con anterioridad como Ilurcis (Curchin, 2004: 21) y refundado por Ti. Sempronius Gracchus en el año 179 a. C. (Hernández Guerra, 2006c: 451) como ciudad romana, no acuñó serie monetaria indígena alguna (Ripollès, 2010: 257); al menos sabemos que no batió ninguna moneda pre-provincial hasta la fecha dada a conocer. Su taller también debió clausurarse en un momento anterior al breve lapso de gobierno de Calígula.

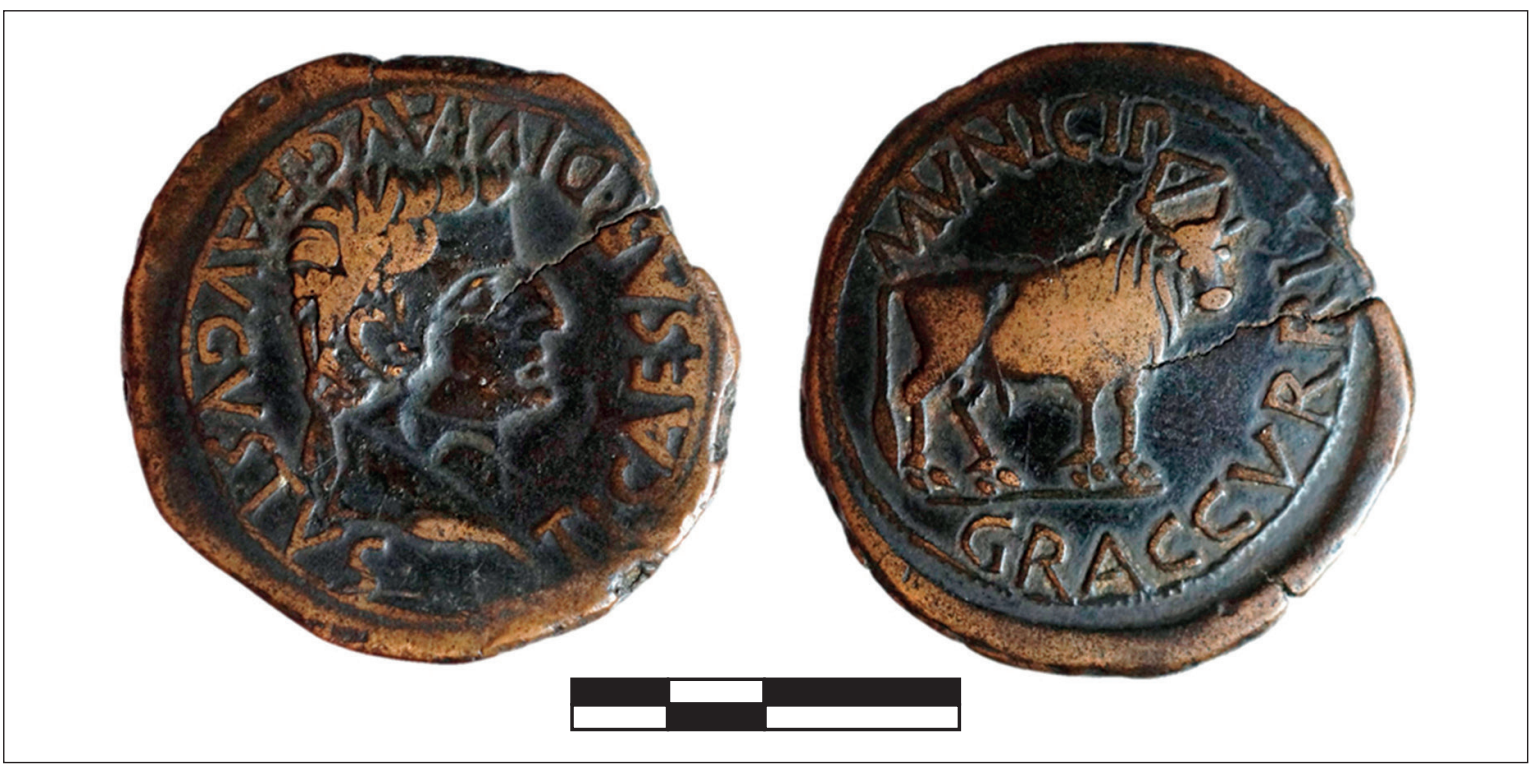

Figura 3

As acuñado en Graccurris bajo el imperio de Tiberio (RPC I, 429)

(MAN 1993/24/6738) (Colección Sastre)

La tercera ceca situada en la zona occidental de la región interior del valle del Ebro que comenzó a acuñar monetario provincial durante el periodo de imperio de Tiberio divulgando el icono del toro fue Clunia (Alto del Cuerno, Coruña del Conde y Peñalba de Castro, Burgos) (RPC I, 452, 454 y 456-457). Pese a que, en contraste con el resto de ciudades emisoras de la zona, parece bastante probable que esta civitas fue promocionada como municipio precisamente en los años tiberianos (Abascal, Espinosa, 1989: 68; De Palol, 1994; Galsterer, 1971: 35; Solana Sainz, 2006: 269), no puede descartarse por completo que este núcleo hubiera obtenido el status de ciudad privilegiada en algún instante de la etapa anterior. Así lo han deducido algunos investigadores (Stylow, 1995: 111; Wiegels, 1985: 104). 
La ciudad de Clunia estaba localizada en un territorio algo apartado del eje de la propia ribera, en dirección suroeste con respecto a la misma. De hecho, se ubicaba en las inmediaciones de otro río importante, el Duero, en una zona no tan alejada del curso del Ebro como otros centros emisores incluidos dentro de esta misma región histórica (como por ejemplo, los municipia de Ercavica y Segobriga). Al igual que Osicerda, Cascantum y Graccurris, Clunia emitió monetario provincial únicamente bajo el periodo de gobierno de Tiberio, precisamente en los momentos en los que debió efectuarse la reapertura de la producción encargada fabricar por la ciudad.

Aún queda por mencionar una ceca de la región que comenzó a acuñar monedas divulgando el icono del toro durante el periodo que en este trabajo se analiza. Nos referimos al municipio de Turiaso (Tarazona, Zaragoza). Este centro también se encontraba situado en la zona occidental del valle del Ebro (Gozalbes Fernández de Palencia, 2009: 1; Hernández Guerra, 2006d: 937), en un área cercana a Calagurris y, sobre todo, a Cascantum y Graccurris, colindante con el territorio central de la propia ribera (García Serrano, 2003-2004: 119-133). A diferencia de aquellas ciudades de la zona más occidental, Turiaso pudo haber sido promocionado como municipio romano (Beltrán Lloris, 2017: 526) ya en época cesariana (Galsterer, 1971: 54 y 71); si bien la mayor parte de autores que han reflexionado acerca de esta cuestión están de acuerdo en deducir que fue durante los años del Segundo Triunvirato (Grant, 1946: 168 y 461; Lostal Pros, 1980: 145) y/o, sobre todo, del Principado cuanto esta civitas obtuvo el régimen de ciudad privilegiada (Amela, 2018: 343; Abascal, Espinosa: 1989: 66; Barceló y Ferrer, 2007: 532; Barrandon, 2011: 250; 2014: 39-40; Beltrán Lloris, 2000: 87; 2017: 531; Beltrán Lloris, Beltrán Lloris, 1980: 162-164; Beltrán Lloris, Paz, Royo: 117-118; Beltrán Lloris, 2002b: 23; Beltrán Martínez, 2002: 62; Bravo, 2007: 79; García-Bellido, 2006a: 689; García-Bellido, Blázquez Cerrato, 2001: 374; Guadán, 1980:101; MacMullen, 2000: 52; Martín-Bueno, 1993: 108-127; Roddaz, 1988: 334; Salinas de Frías, 1986: 151; Sancho Rocher, 1981: 135).

Precisamente durante estos primeros instantes de la etapa augustea Turiaso comenzó también a acuñar moneda provincial (Ripollès, 2010: 242). No obstante, durante este periodo los individuos que controlaban la fabricación de moneda del taller turiasonense (que según testimonian algunas monedas pudieron ser duunviros) decidieron que las series que sancionaron no adoptaran aún la imagen del toro, sino que, optaron por divulgar una representación re-fundacional y/o de una diosa indígena (RPC I, 401-404), y el icono de la corona cívica como tipología principal de reverso (RPC I, 405-408 y 410-411; RPC S2-I-407A).

Aunque la iconología de la corona cívica continuó siendo difundida como tipo principal en la mayor parte de series tiberianas emitidas por esta ceca (RPC I, 413-416 y 421), en los momentos de imperio de Tiberio los grabadores de cuños contratados por la misma cincelaron también la imagen del toro en los reversos de algunas de las acuñaciones que fabricaron (RPC I, 417-419). Por tanto, Turiaso fue la única ciudad de la región que no divulgó el icono taurino en las primeras décadas de actividad monetaria hispanorromana de su oficina. Los magistrados que autorizaron la elaboración de monedas del municipio optaron por que las piezas de fábrica turiasonense 
comenzaran a adoptar esta representación tras una primera etapa de producción de ejemplares provinciales del centro, seguramente en los momentos en los que el icono ya se había asentado como el principal emblema monetario de la región.

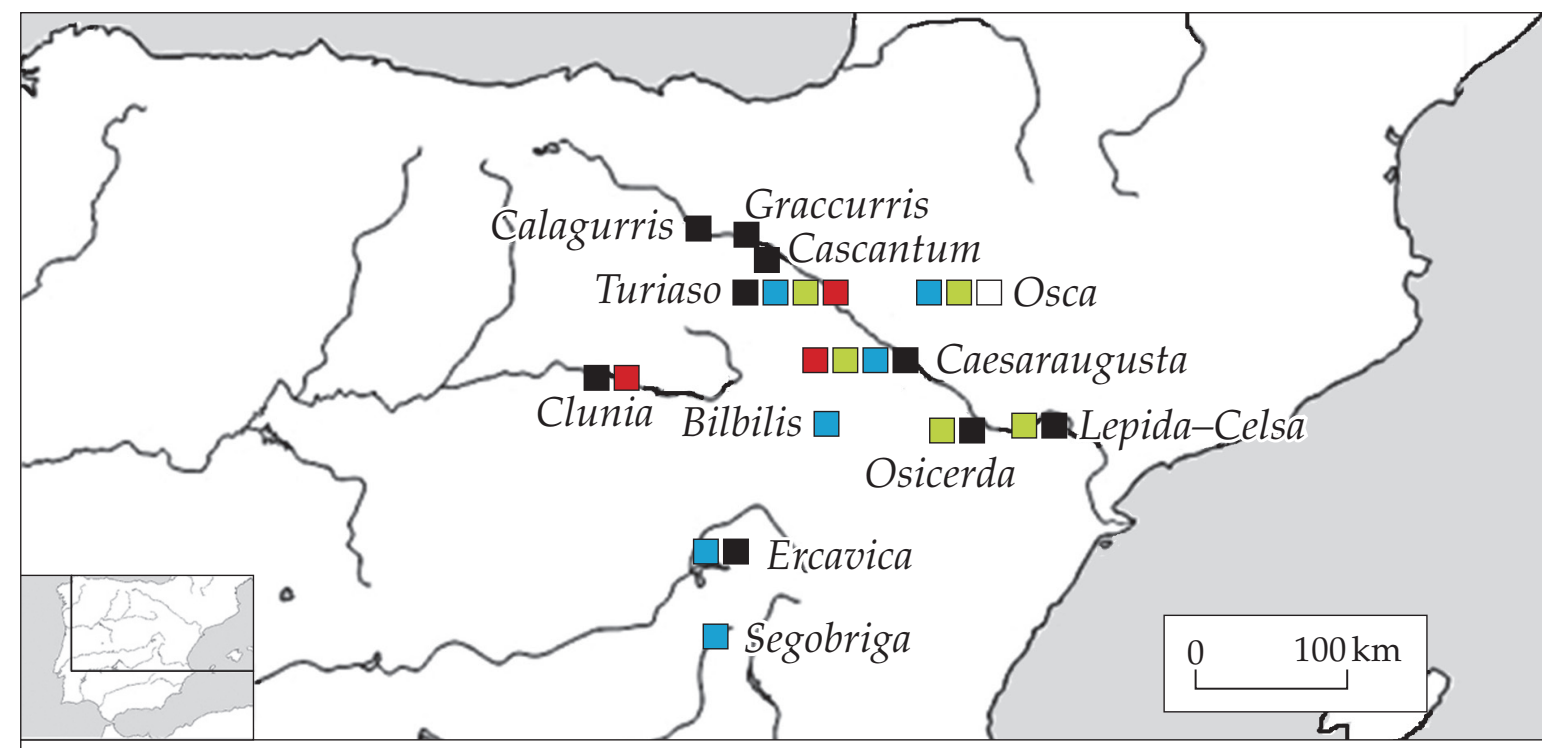

Cecas provinciales tiberianas de la región del valle del Ebro que adoptaron el tipo toro en su monetario

Cecas provinciales tiberianas de la región del valle del Ebro que adoptaron el tipo jinete lancero en su monetario

Cecas provinciales tiberianas de la región del valle del Ebro que adoptaron el tipo corona cívica en su monetario

Cecas provinciales tiberianas de la región del valle del Ebro que adoptaron el tipo epigráfico en su monetario

Cecas provinciales tiberianas de la región del valle del Ebro que adoptaron otras imágenes como tipologías de reverso en su monetario

\section{Figura 4}

Localización de las iconologías de reverso adoptadas en el monetario tiberiano fabricado por las cecas dispersadas por la región del valle del Ebro, según ceca de emisión e icono

Llama la atención la circunstancia de que el municipio de Turiaso se encontrase situado en un territorio mucho más cercano al resto de centros que en época augustea ya habían emitido moneda con la iconología del toro como eran, en efecto, LepidaCelsa y, sobre todo, Caesaraugusta y Calagurris. Un fenómeno bastante similar puede observarse en lo concerniente a las emisiones de otra ciudad próxima, esto es el municipio de Bilbilis, cuya producción monetaria no incluyó ningún ejemplar relacionado con esta imagen de reverso.

Aun cuando las circunstancias anteriormente comentadas puedan parecer intrascendentes, resultan de gran importancia. Estos hechos evidencian que, pese a que la difusión de la iconología del toro experimentó una divulgación progresivamente general en la región interior del valle del Ebro, su propaganda no estuvo relacionada de manera absolutamente directa con la proximidad de unos centros con respecto a 
otros. Igualmente, resulta de gran interés recordar que durante este periodo el régimen jurídico de las distintas ciudades emisoras de la región tampoco fue un factor totalmente decisivo en el proceso de selección de la emblemática monetaria. Con todo, las proyecciones iconológicas divulgadas en los reversos del monetario acuñado en época tiberiana pudieron ser muy variadas en las distintas colonias y municipios emisores y, de hecho, el icono del toro fue adoptado en las piezas emitidas tanto por ciudades coloniales como por municipia romanos y latinos.

\begin{tabular}{|c|c|c|c|c|c|}
\hline & Toro & Jinete & $\begin{array}{l}\text { Corona } \\
\text { cívica }\end{array}$ & $\begin{array}{c}\text { Tipo } \\
\text { epigráfico }\end{array}$ & Otros \\
\hline Lepida-Celsa & As & --- & --- & Semis & --- \\
\hline \multirow{2}{*}{ Osca } & \multirow{2}{*}{--} & \multirow{2}{*}{ As } & \multirow{2}{*}{ Cuadrante } & Semis & \multirow{2}{*}{---} \\
\hline & & & & Cuadrante & \\
\hline \multirow{4}{*}{ Caesaraugusta } & \multirow{4}{*}{ As } & \multirow{4}{*}{---} & \multirow{4}{*}{ Dupondio } & Sestercio & Sestercio \\
\hline & & & & Dupondio & Dupondio \\
\hline & & & & \multirow{2}{*}{ Semis } & As \\
\hline & & & & & Semis \\
\hline \multirow{2}{*}{ Bilbilis } & \multirow{2}{*}{---} & \multirow{2}{*}{---} & As & \multirow{2}{*}{---} & \multirow{2}{*}{---} \\
\hline & & & Semis & & \\
\hline \multirow{3}{*}{ Turiaso } & \multirow{3}{*}{ As } & \multirow{3}{*}{---} & \multirow{2}{*}{ As } & \multirow{2}{*}{ Semis } & Sestercio \\
\hline & & & & & As \\
\hline & & & Semis & Cuadrante & Semis \\
\hline \multirow{2}{*}{ Cascantum } & As & \multirow{2}{*}{---} & \multirow{2}{*}{---} & \multirow{2}{*}{---} & \multirow{2}{*}{---} \\
\hline & Semis & & & & \\
\hline \multirow{2}{*}{ Graccurris } & As & \multirow{2}{*}{---} & \multirow{2}{*}{---} & \multirow{2}{*}{---} & \multirow{2}{*}{---} \\
\hline & Semis & & & & \\
\hline \multirow{2}{*}{ Calagurris } & As & \multirow{2}{*}{---} & \multirow{2}{*}{---} & \multirow{2}{*}{---} & $\ldots$ \\
\hline & Semis & & & & -- \\
\hline Clunia & As & --- & --- & --- & Semis \\
\hline Ercavica & As & -- & Semis & --- & --- \\
\hline Osicerda & As & --- & --- & Semis & --- \\
\hline Seoohriog & _.- & -.- & As & --- & --- \\
\hline & & & Semis & & \\
\hline
\end{tabular}

Figura 5

Iconologías de reverso adoptadas en el monetario provincial tiberiano emitido por las cecas localizadas en la región histórica del valle del Ebro, según ceca de acuñación de las series y valores relativos a las mismas 
Sin embargo, pese a lo advertido en el párrafo anterior, los datos detallados evidencian que la totalidad de cecas ubicadas en esta región que comenzaron a acuñar ejemplares provinciales durante la extensa etapa de imperio de Tiberio adoptaron el icono del toro en algunas de las monedas que emitieron. Sin duda alguna, esta circunstancia acredita la importancia ideológica que esta imagen tenía en las diversas ciudades emisoras de la zona, pues confirma que los individuos que controlaban la producción de monedas de todos los centros hispanorromanos que no se habían relacionado previamente con un icono optaron por vincular de manera efectiva la emblemática monetaria provincial de las ciudades que gobernaban con esta particular iconología.

Algunas de aquellas cecas que comenzaron a emitir monetario provincial en la época del emperador Tiberio ya habían acuñado series indígenas divulgando la representación del jinete ( $\mathrm{CNH}$ 258.1, 259.2-4 y 283.2-4) pese a lo cual decidieron dejar de identificarse con aquella tradicional emblemática durante los años en los que fabricaron monedas hispanorromanas. Aunque, la imagen tradicional del jinete, en estos momentos ya siempre lancero, no fue olvidada por completo, había comenzado a experimentar un declive progresivo desde el comienzo de la etapa imperial romana, que fue especialmente visible a partir de los últimos años del principado de Augusto.

Si en los comienzos de la etapa augustea habían acuñado series recogiendo la imagen del jinete 3 cecas distintas de la región (RPC I, 283-285, 287, 289, 387-391 y 472) tras la muerte del princeps tan solo una de ellas continuó difundiendo aquella tipología monetaria (RPC I, 291, 295-297, 300 y 302). Es cierto que los magistrados de estos 3 centros decidieron no sustituir una imagen por otra (RPC I, 392-400 y 473-477), evidenciando de aquel modo la posible percepción contrapuesta que podría haber existido entre ambas iconologías. También resulta incuestionable que muchas de las monedas con tipo jinete acuñadas con anterioridad pudieron seguir utilizándose, pues las diversas contramarcas atestiguadas en algunos ejemplares así pueden testimoniarlo ( $R P C$ I, 283-284 390-391 y 472; RPC S2-I-285 y 388-391; RPC S3-I-283-284; RPC S5-I-391).

Sin embargo, los datos sobre producción monetaria evidencian que la divulgación del icono del toro en los ejemplares de nueva acuñación fabricados en época tiberiana era realmente significativa. La dimensión representativa-regional de esta iconología no debió ser percibida de manera negativa, ni mucho menos rechazada, por los propios habitantes de la mayor parte de centros situados en la zona, los cuales, según puede intuirse, debieron aceptar esta imagen como un icono emblemático de los lugares en los que vivían sin ningún tipo de conflicto ni recelo aparente.

De hecho, a la vista de las informaciones sobre producción detallados en párrafos anteriores, podría incluso plantearse, tal y como nos ha sugerido algún investigador, la posibilidad de que el interés de las autoridades monetarias y de los habitantes de los centros por relacionarse con la emblemática del toro se gestara en un momento anterior a la elaboración de las propias emisiones. Con todo, estas cecas no tuvieron actividad en los primeros momentos de proyección de esta iconología monetaria en el territorio y, por tanto, las novedades ideológicas no pueden visualizarse de manera totalmente efectiva a partir del documento numismático. 
En cualquier caso, resulta sobre todo evidente que esta particular proyección identitaria debió experimentar una evidente consolidación e, incluso fortalecimiento, en las ciudades de Lepida-Celsa, Caesaraugusta, Calagurris y Ercavica, pues, como se ha mencionado, estos centros continuaron emitiendo piezas con la iconología del toro en algunas de las series tiberianas que pusieron en empleo.

\section{LA ICONOGRAFÍA DEL ICONO DEL TORO EN LAS MONEDAS TIBERIANAS EMITIDAS EN LA REGIÓN INTERIOR DEL VALLE DEL EBRO}

En cuanto a los aspectos iconográficos relacionados con la iconología monetaria del toro, a partir del periodo del Principado se divulgaron tres tipos de imágenes distintas, que continuaron siendo difundidas en los años tiberianos. Estas representaciones fueron las siguientes:

- Imagen de toro de cuerpo entero, de pie sobre la línea de exergo, en posición estática y sin adornos. Esta propuesta iconográfica fue la de mayor divulgación. Se adoptó en algunos ases acuñados por Lepida-Celsa, Turiaso, Calagurris y Clunia y, en la totalidad de monedas fabricadas por Cascantum.

- Imagen de toro de cuerpo entero, de pie sobre la línea de exergo, en posición estática y adornado con una mitra. Esta representación fue grabada en diversos ases acuñados por orden de Caesaraugusta, Graccurris y Ercavica.

- Imagen de cabeza de toro de frente. Este tipo fue seleccionado para su exposición en la totalidad de semises puestos en uso por Graccurris y Calagurris.

A la vista de los aspectos iconográficos de todas las monedas que adoptaron la iconología del toro en época de Tiberio puede concluirse que las producciones fueron únicas y originales en cada ceca, ya que todas estas ciudades adaptaron las distintas representaciones a una propuesta de selección por valores monetarios y exposición epigráfica particular de cada centro ${ }^{4}$. Si observamos con detenimiento las series emitidas por todas las cecas documentadas advertimos una enorme dificultad en poder poner en relación unas producciones y otras. Este hecho resulta de enorme importancia, sobre todo, si recordamos que, como se ha advertido brevemente en el punto anterior, los aspectos estilísticos de algunas piezas sugieren que las monedas con toro acuñadas por los municipia de Turiaso, Cascantum, Graccurris y Clunia pudieron ser fabricadas en una misma oficina.

${ }^{4}$ El estudio de las fórmulas epigráficas que acompañaron esta iconología en el monetario tiberiano será objeto de futuros trabajos. Tan sólo creemos oportuno advertir en estos párrafos que mientras que las series batidas por Cascantum, Graccurris y Osicerda recogieron letreros muy breves, referentes a partir de determinas abreviaturas al nombre de la ciudad emisora y su status jurídico, las emisiones de Lepida-Celsa, Turiaso, Calagurris y Ercavica incorporaron además leyendas también abreviadas alusivas a los nominae de algunos de los posibles magistrados que actuaron como autoridades monetarias locales. Además, aunque la mayor parte de piezas caesaraugustanas incluyeron letreros llamativamente escuetos que aludía a partir de tres palabras al nombre de la colonia y su reglamento jurídico, algunos ejemplares acuñados por esta ciudad también referenciaron el nombre de los individuos que debieron de autorizaron la fabricación de los mismos. 
Estos datos documentan el gran interés que pudieron tener las autoridades monetarias de los distintos centros por individualizar las producciones que se encargaron de sancionar. Además, aunque no podemos concluir de manera totalmente segura que los usuarios de las piezas estuvieran en condiciones de observar en todos los casos estas diferencias, pues los hallazgos arqueológicos no acreditan el uso en los distintos sitios de las series acuñadas por todas las cecas, es bastante probable que en las ocasiones en las que se pudo contrastar unas producciones y otras las diferencias hubieran sido detectadas.

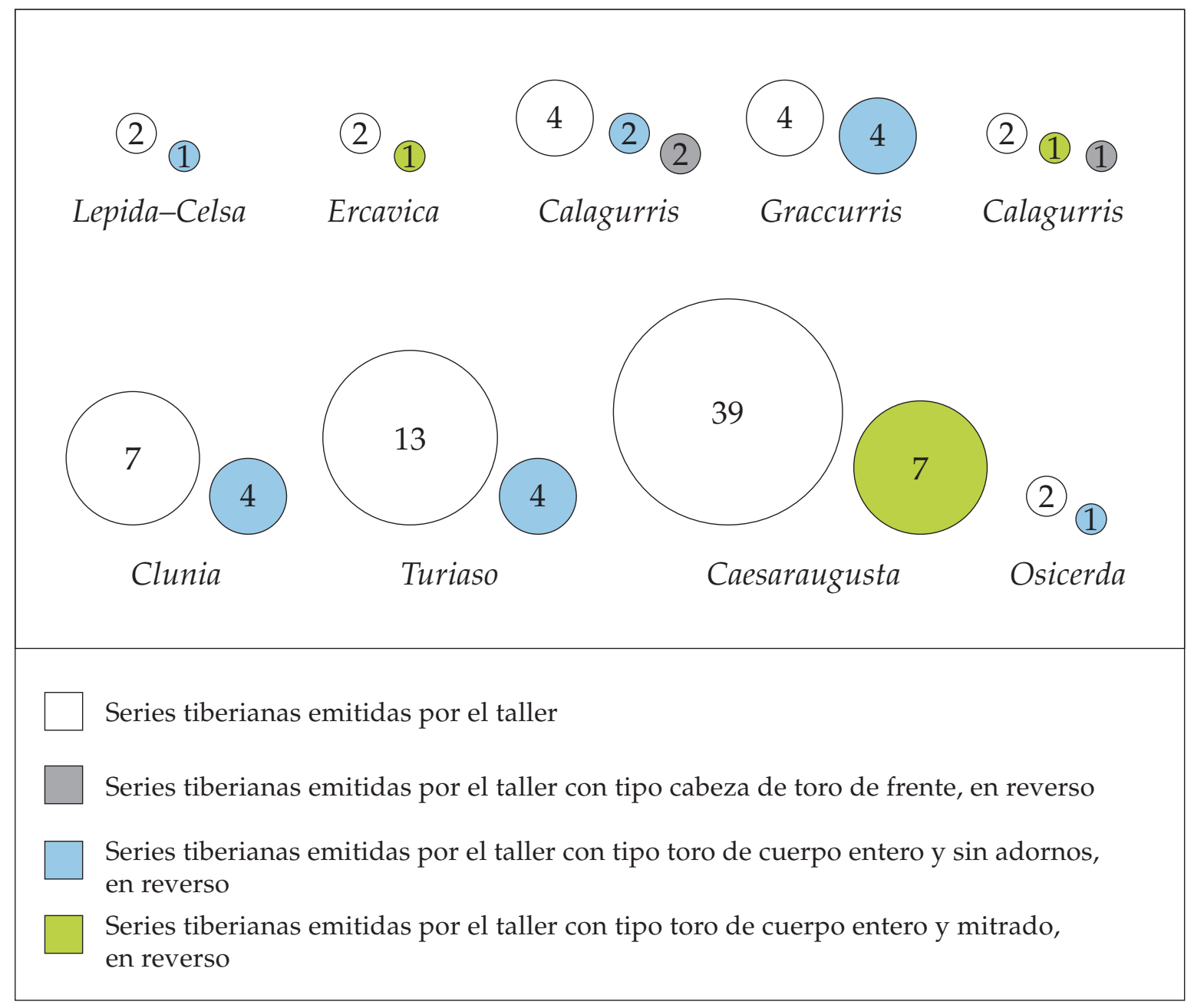

\section{Figura 6}

Cálculo de distribución de las distintas iconografías asociadas a la iconología del toro en las monedas batidas en las cecas tiberianas localizadas en la región del valle del Ebro, en relación con la producción monetaria total de las mismas, según centro emisor y número de series fabricadas ${ }^{5}$

\footnotetext{
5 Hemos optado por no incluir la emisión de ases catalogada como RPC S3-351A, ya que, tal y como advierte el autor que la documenta, aunque las otras combinaciones de cuños verificadas en la producción de la ceca sugieren su probable acuñación, aún no se ha verificado ningún ejemplar relativo a dicha serie (Ripollès, 2010: 223).
} 
Por consiguiente, la incidencia de un nivel de emblemática local relacionado con esta iconología monetaria resulta innegable, al menos por lo que respecta a la las series acuñadas bajo el imperio de Tiberio. Ahora bien, a nuestro juicio, pese a que este nivel de expresión representativa que podía identificar a cada ceca es evidente, y sabemos que se desarrolló de manera desigual según cada centro emisor, también resulta bastante probable que, al mismo tiempo, estas imágenes se incluyeran dentro de una simbología mucho más general, vinculada con la proyección identitaria de la región interior del valle del Ebro. De este modo pudo ser concebido tanto por los usuarios de los centros de la propia región, como por los habitantes de otras zonas hispanas, los cuales al contemplar una pieza con iconología taurina pudieron estar en condiciones de relacionarla con estos territorios interiores de la provincia Citerior Tarraconensis. Son 3 los argumentos que pueden razonar la hipótesis que sobre este asunto defendemos.

En primer lugar, debe tenerse en cuenta que todas las propuestas iconográficas atestiguadas en el monetario tiberiano mantuvieron al toro como la figura protagonista. De hecho, la representación del animal apareció en todos los casos en el centro de la moneda, ocupando casi todo el espacio del cospel monetario. El tamaño de aquella imagen permitía que fuese fácilmente reconocible y, en la mayor parte de las emisiones los rasgos principales del bóvido fueron notablemente detallados. Es más, aunque, como se ha aludido, en algunas series se grabó la representación de un toro ornamentado, mientras que en otras, en cambio, se revelaba sin arreos, los adornos que se decidieron cincelar siempre presentaron un tamaño poco significativo y se expusieron en la parte superior de la moneda de manera que su presencia no desplazaba la imagen del bóvido de la zona central de la misma.

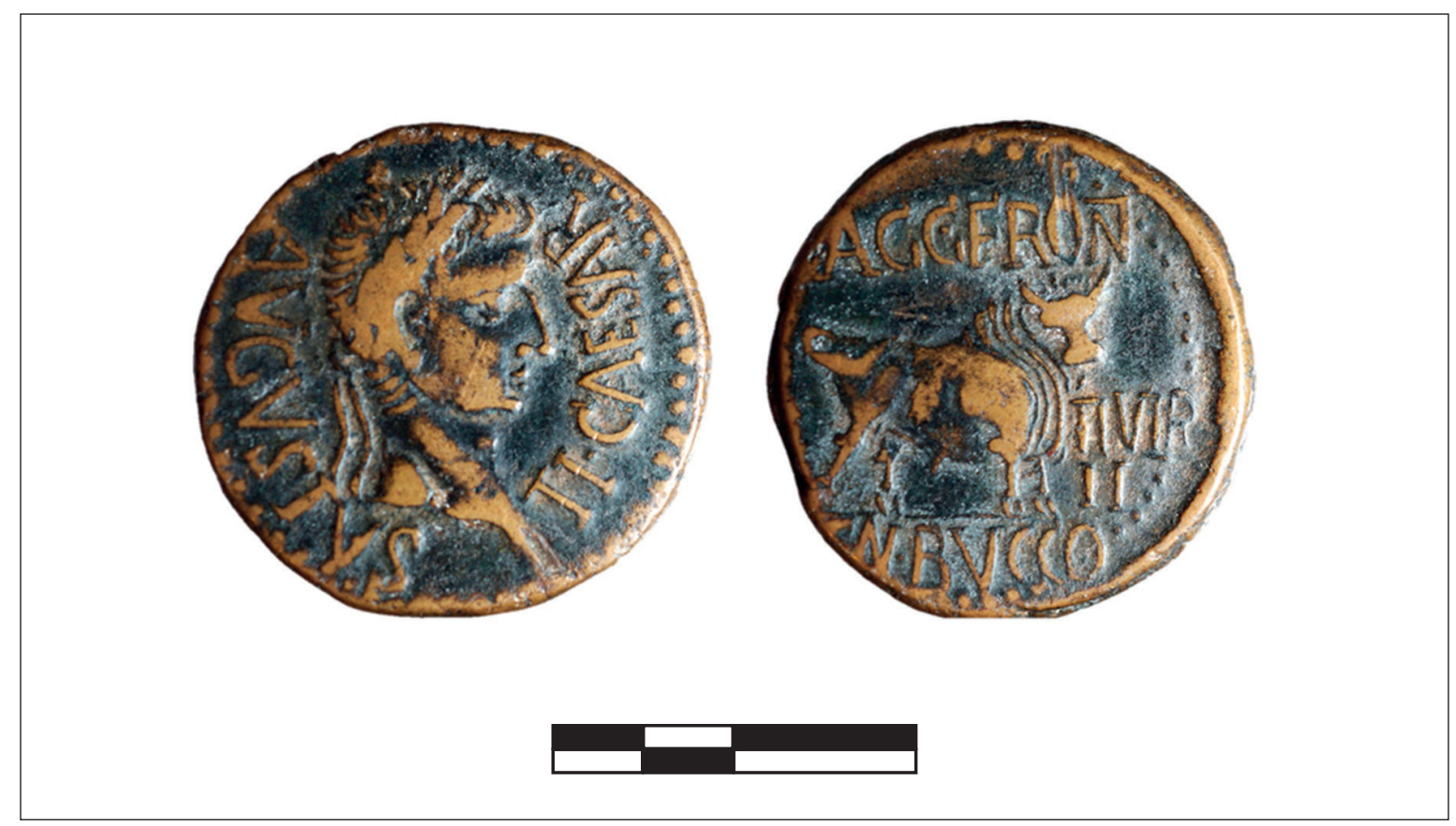

Figura 7

As acuñado en Lepida-Celsa bajo el imperio de Tiberio (RPC I, 279b) (MAN 1993/67/10037) 
En segundo lugar, en estrecha relación con la idea anteriormente comentada, es de interés también cuestionarse cuál pudo ser la motivación que podría haber inducido a todas estas ciudades a seleccionar la representación del mismo animal, es decir la de un toro, pues resulta bastante difícil concebir que lo hicieran si deseaban hacer referencia a iconos y símbolos distintos. Con todo, la variedad de imágenes conocidas que pudieron en aquellos momentos seleccionarse para su exposición en el monetario era especialmente significativa. Por este motivo, resulta poco razonable interpretar que cada figura se relacionó con una iconología y simbología particular, dado que además todas las representaciones fueron divulgadas en el mismo territorio y a través de los mismos canales de difusión visual, es decir los intercambios inter-regionales de la zona en los que eran utilizadas las monedas acuñadas por las cecas ubicadas en esta región.

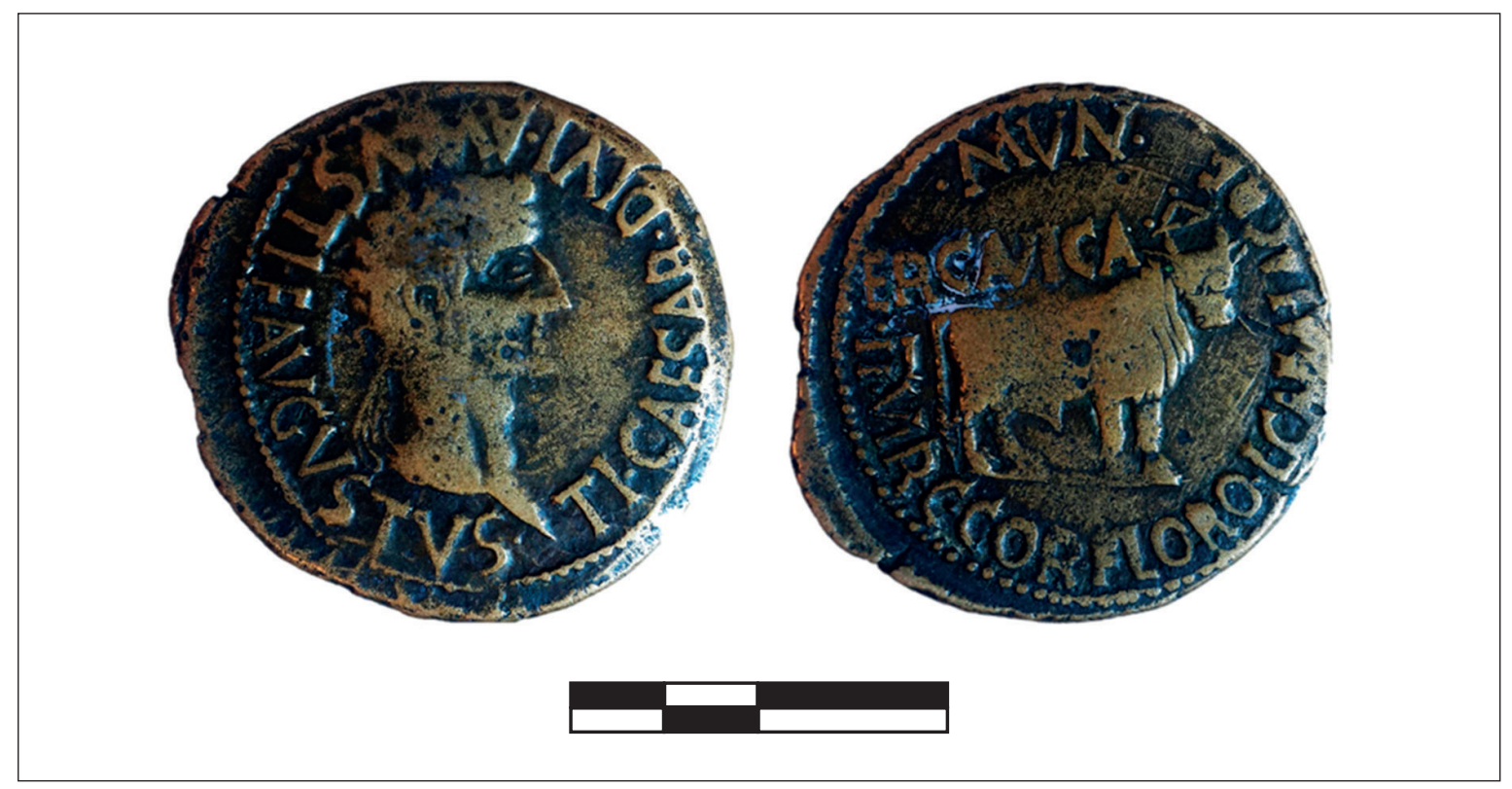

Figura 8

As acuñado en Ercavica bajo el imperio de Tiberio (RPC I, 462a) (MAN 1993/67/11239)

De acuerdo con todas estas argumentaciones podría considerarse la especial circunstancia de que los usuarios de estas piezas difícilmente estuvieran en condiciones de interpretar de manera totalmente distinta unas imágenes y otras, pues, como hemos señalado, en todas ellas el toro era siempre la figura protagonista. Es cierto que para muchos de estos usuarios las diferencias iconográficas pudieron ser reconocibles e incluso podría plantearse la posibilidad de que estas variadas propuestas visuales fuesen en algunos casos altamente llamativas para quienes tuvieron la posibilidad de compararlas. Pero, sin duda alguna, los usuarios de estos ejemplares debieron relacionar todas las representaciones entre sí, considerando que eran iconos representados a partir de figuras diversas pero que se vinculaban a una misma simbología. De este modo debieron de haberlo concebido los propios comitentes del monetario, pues seguramente fueron conscientes previamente de que una vez que las piezas estuvieran en manejo, quienes las utilizaran día a día terminarían por ponerlas en relación directa. 


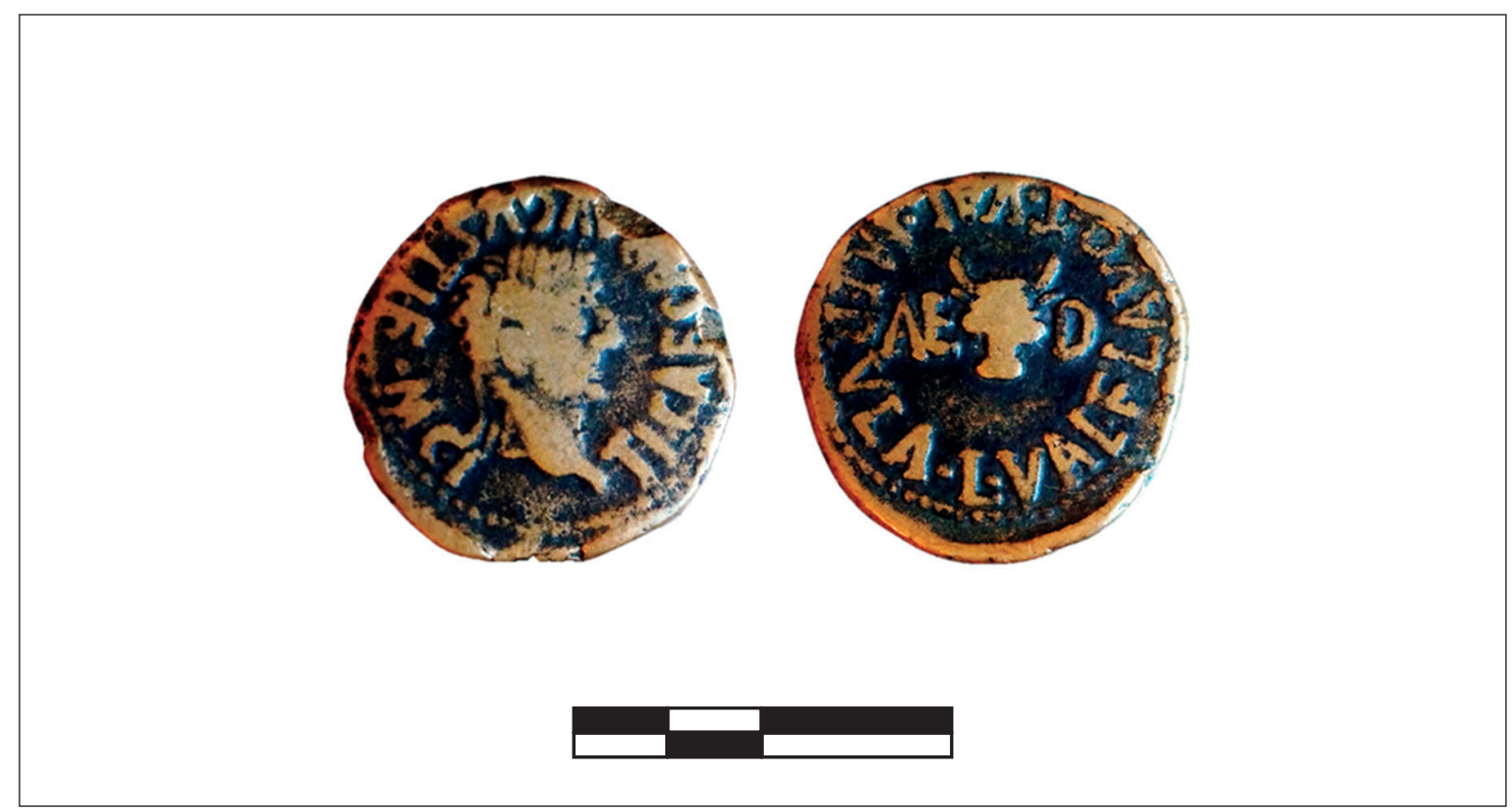

Figura 9

Semis acuñado en Calagurris bajo el imperio de Tiberio (RPC I, 449) (MAN 1993/67/8727)

Finalmente, en tercer lugar, podría ser del mismo modo revelador tener en cuenta que la ciudad de Ercavica comenzó a emitir monetario con la imagen del toro sin ornamentar en los primeros años del Principado (RPC I, 459-460) y una vez que se conoció la representación mitrada (como se ha aludido seguramente a partir del año 7 d. C. [RPC I, 327-328]) el municipio decidió variar su iconografía (RPC I, 459-462). Esta evolución, que se atestigua a partir de los años de gobierno de Tiberio, podría explicarse interpretando que los individuos que controlaban la producción de aquella ceca optaron por cambiar los aspectos iconográficos de la tipología divulgada una vez que conocieron la innovación figurativa. Con todo, resulta muy difícil imaginar que estas autoridades decidieran cambiar el relato simbólico de su monetario manteniendo la misma figura principal que en las monedas acuñadas en el periodo anterior (esto es la del bóvido).

Aunque las variadas propuestas iconográficas asociadas a la iconología monetaria del toro evidencian el desarrollo de una emblemática local que pudo ser bastante indiscutible para los usuarios de las piezas y que partía de un manifiesto interés por parte de las autoridades monetarias por individualizar las producciones de cada centro, estas variaciones no fueron lo suficientemente acentuadas como para poder madurar distintas proyecciones de tipo simbólico que se relacionaran directamente con la propia iconología. A priori, parece evidente que en la mayor parte de los casos las distintas representaciones se relacionaron con un mismo relato simbólico y, que lograron crear una narrativa emblemática regional bastante reconocible. No obstante, como se tratará en los puntos siguientes, los datos de producción de cada ceca sugieren el posible desarrollo de eventualidades relacionadas con la proyección simbólica de determinados centros. 


\section{EL INDISCUTIBLE PROTAGONISMO DEL ICONO DEL TORO EN LOS ASES Y SEMISES TIBERIANOS EMITIDOS POR LA MAYOR PARTE DE CECAS DE LA REGIÓN}

Durante el periodo de imperio de Tiberio el icono del toro fue adoptado en el monetario fabricado por la mayor parte de las cecas de la región interior del valle del Ebro como el tipo principal de reverso. De hecho, de las 9 ciudades emisoras ubicadas en este entorno que en estos años seleccionaron esta iconología, 7 la incluyeron en todas las series relativas a la especie de mayor producción y uso en la región que se analiza, es decir, el as (Ripollès, 2010: 21). Es más, los datos de emisión hasta el momento verificados sugieren que los individuos que controlaron la fabricación monetaria de algunas de estas ciudades decidieron que el icono del toro fuese el único tipo de reverso grabado en la totalidad de series tiberianas que dichos centros pudieron haber fabricado (RPC I, 425-430 y 448-451).

Entre las 7 ciudades en cuyas emisiones relativas a ases la imagen del toro fue el tipo exclusivo de reverso, se encontraban 3 de las 4 cecas que en época anterior ya habían fabricado monetario divulgando esta representación. Debe recordarse, además, que durante aquel periodo del Principado las autoridades de estas 3 cecas ya habían autorizado esta política de selección tipológica basada en la adopción de este icono como tipo exclusivo de reverso de la totalidad de ases que ordenaron acuñar (RPC I, 270-273, 278, 431, 433-441, 444-447 y 459-460). No obstante, los datos sugieren que en estos momentos la producción de todas estas ciudades debió disminuir considerablemente. Ahora bien, el uso de las monedas batidas por aquellos centros con anterioridad divulgando aquella iconología no debió paralizarse, de modo que estas piezas y las imágenes grabadas en ellas continuaron difundiéndose. De este modo los podrían documentar los numerosos ejemplares que fueron contramarcados (RPC I, 262-264, 269-271, 273, 278, 433-439, 441, 444-447 y 459; RPC S2-I-, 434-439, 441, 444-445, 447 y 459; RPC S3-I-270, 273, 439 y 441; RPC S4-I-435-436; RPC S5-I-278, 433, 439 y 459) y cuyo uso en época tiberiana podría justificar el descenso en las acuñaciones de dichos centros.

Si en el periodo augusteo Lepida-Celsa había acuñado 5 series distintas de unidades base (RPC I, 270-273 y 278), en estos momentos la producción de ases del taller asociado a la misma disminuyó drásticamente. Hasta tal punto pudo ser así que, a la vista de los datos hasta la fecha conocidos, se deduce que durante este periodo la ceca batió tan sólo una única serie de unidades base (RPC I, 279). Según se ha podido comprobar, esta emisión presentó una variante en el modo de exposición de su leyenda de reverso (RPC I, 279a-b); práctica que también fue habitual en las monedas acuñadas por esta colonia con anterioridad (RPC I, 261a-b, 268a-b, 269a-f, 270a-o y 278a-f). No cabe duda de que la verificación de esta única variación en el monetario lepidano-celsano de fábrica tiberiana puede testimoniar el probable gran volumen de ejemplares batidos relativos a esta serie (Hurtado, 2013: 366) y, por tanto, la cantidad de piezas con esta tipología que pudieron encontrarse a disposición de los usuarios. 


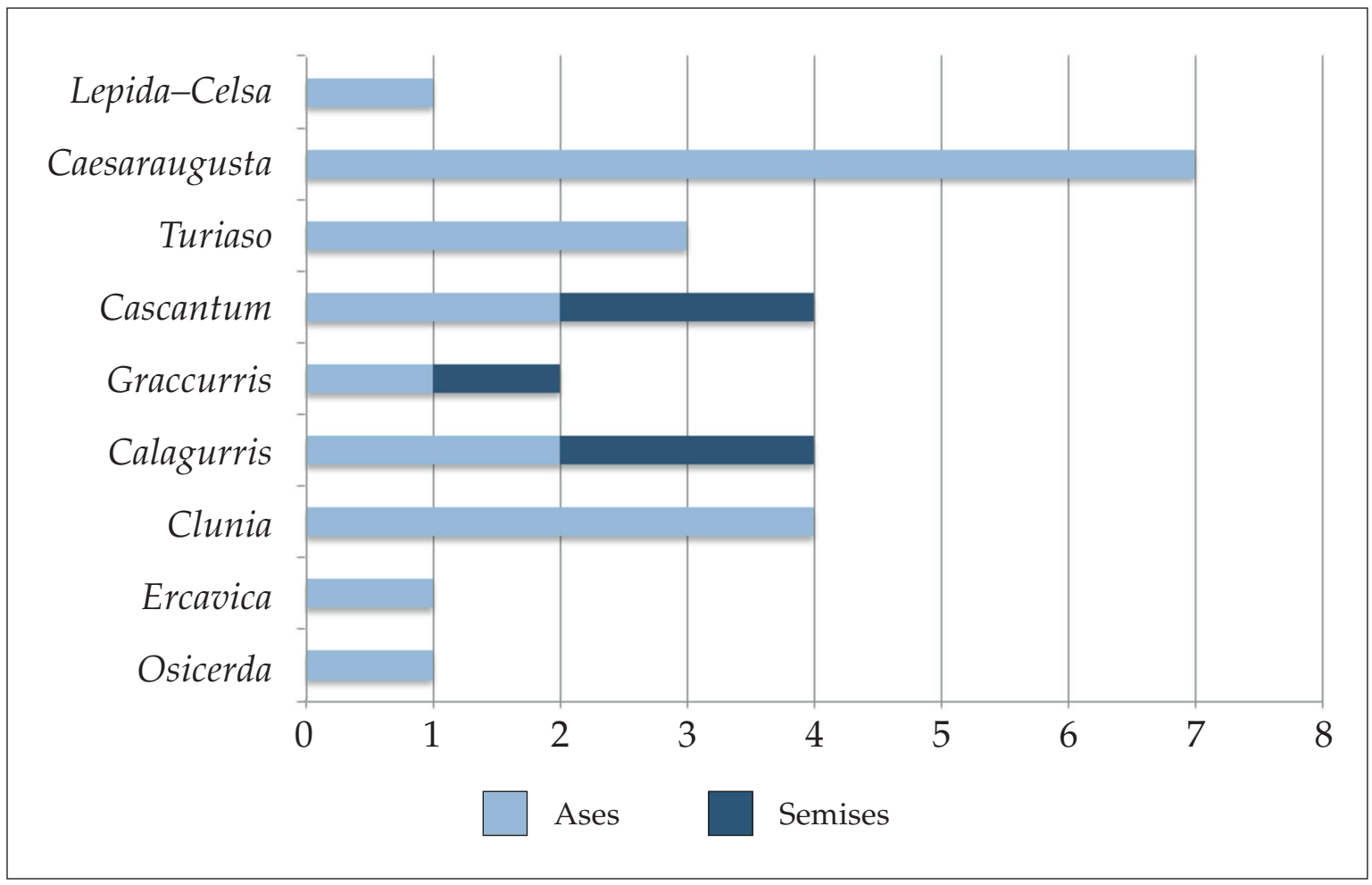

Figura 10

Cálculo de la distribución por valores monetarios de las monedas con iconología del toro como tipología de reverso acuñadas en las cecas tiberianas localizadas en la región del valle del Ebro, según centro emisor y número de series fabricadas

Muy similar fue la fabricación de monedas en bronce tiberianas relativas a la unidad base constatada en el taller asociado al municipio de Ercavica. Los datos que hasta el momento se conocen verifican que esta ceca también puso en circulación tan solo una emisión de ases, nuevamente divulgando la iconología del toro como tipología preferente (RPC I, 462). Es cierto que en época anterior la producción de denominaciones base de este centro fue también bastante exigua (RPC I, 459-460), especialmente si se compara con la verificada en el resto de cecas cercanas. No obstante, resulta evidente que la fabricación de numerario ercavicense hubo de ser aún menor durante los años de gobierno de Tiberio. Al igual que advertíamos en el caso de las emisiones lepidano-celsanas, la serie de ases tiberiana fabricada por Ercavica presentó una variante conocida, relativa, como era habitual en la ceca, al modo de exposición de su leyenda de reverso (RPC I, 462a-b). Esta variación, como en el caso de la serie tiberiana acuñada por Lepida-Celsa comentada en anteriores párrafos, podría sugerir que el número de ejemplares relacionados con la misma fuese bastante alto.

En aquellos momentos, la ceca de Calagurris también disminuyó su producción monetaria. A la vista de las informaciones publicadas, puede intuirse que este centro pudo poner en circulación tan solo dos acuñaciones distintas de ases, nuevamente, con la iconología del toro como tipo único de reverso (RPC I, 448 y 450). Estos números contrastan por completo con el volumen de emisión augustea del centro, pues 
según las cifras hasta el momento calculadas Calagurris pudo acuñar durante el Principado 14 series distintas de ases (RPC I, 431, 433-441, 444-447 y 459-460), las cuales en algunos casos presentaron una gran cantidad de variaciones (RPC I, 437a-c, 440a-g, 441a-d, 444a-f y 445-446a-f).

Siguiendo esta política de producción monetaria, y de manera algo más acusada de lo que puede verificarse con respecto a las acuñaciones fabricadas en estos momentos por las oficinas asociadas a Lepida-Celsa y Ercavica, las emisiones de ases tiberianos calagurritanos presentaron un número bastante significativo de variantes en la configuración de sus leyendas, que, en este caso, se relacionaban tanto con los rótulos de anverso, como con los de reverso (RPC I, 448a-d y 450a-e). Por tanto, podemos deducir que el número de piezas relativas al valor base que esta ceca acuñó en los años del imperio de Tiberio fue considerablemente mayor que la cifra de monedas puestas en circulación por los centros detallados en anteriores párrafos.

Por otra parte, se encontraban las nuevas ciudades que comenzaron a acuñar monetario con esta tipología durante los años de gobierno tiberiano. Los individuos que autorizaron la producción monetaria de casi todas estas cecas también decidieron que los ases que desde aquellas se emitieron adoptaran la iconología del toro como representación exclusiva de reverso. Entre estas cecas se encontraba Cascantum, que, al igual que Calagurris, puso en circulación dos emisiones distintas de ases (RPC I, 425 y 427). Graccurris, por su parte, batió tan solo una serie de unidades base en bronce (RPC I, 429), al igual que Osicerda (RPC I, 468). Ninguna de las acuñaciones de ases puestas en uso por estas tres cecas presentó variantes actualmente conocidas; por este motivo podría concluirse que el número de piezas relacionadas con las mismas pudo ser menor que la cifra de ejemplares relacionados con las acuñaciones enumeradas en anteriores párrafos.

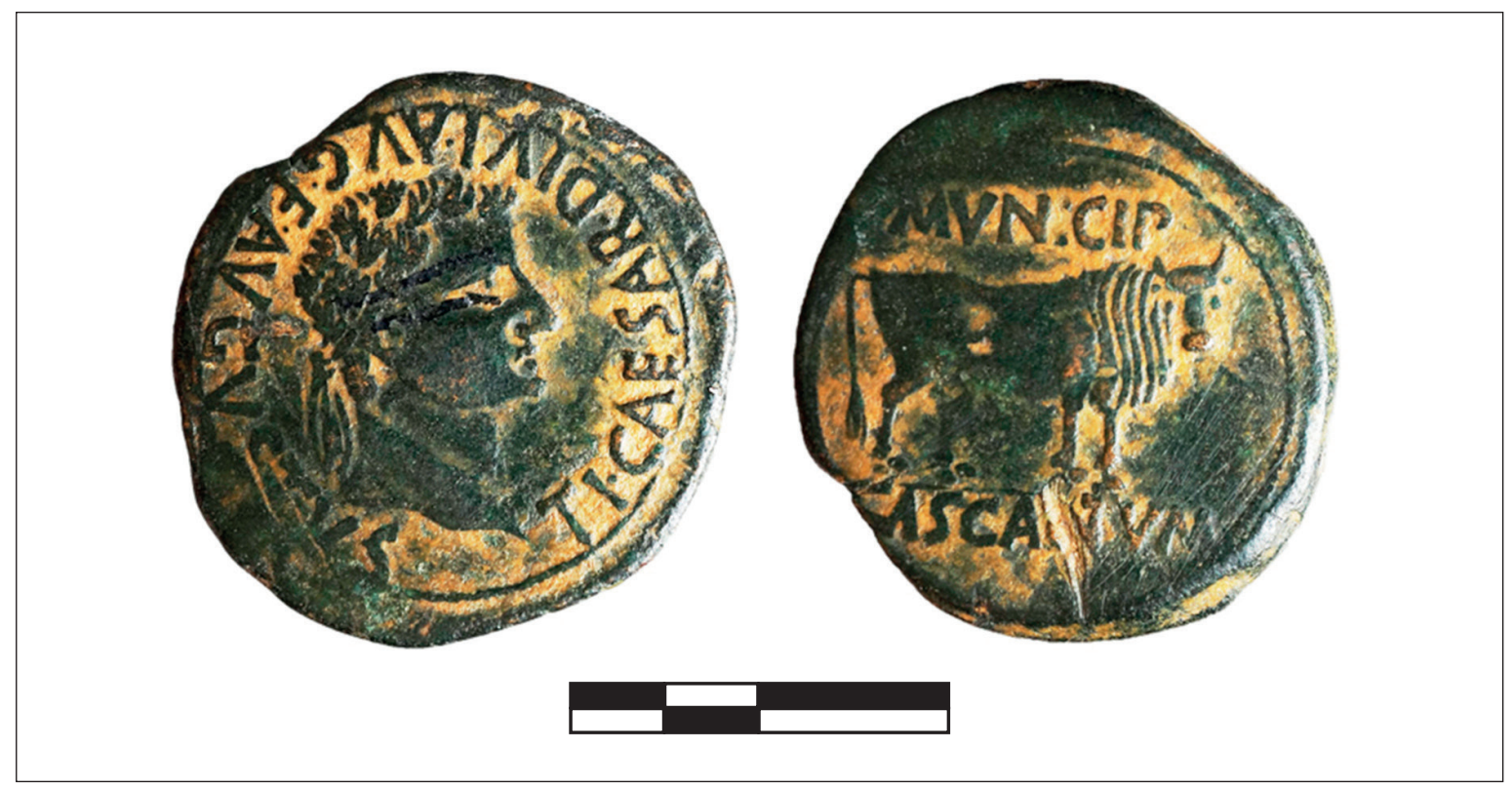

Figura 11

As acuñado en Cascantum bajo el imperio de Tiberio (RPC I, 427) (MAN 1993/67/9632) 
El taller vinculado con el municipio de Clunia batió un número mayor de emisiones de ases que el resto de cecas detalladas. Conforme a los datos de fabricación monetaria publicados, sabemos que el municipio pudo poner en circulación hasta tres series de unidades base en bronce distintas (RPC I, 452, 454, 456 y 457). Dos de estas acuñaciones presentaron un cuantioso número de variantes en el modo de exposición de sus leyendas de reverso (RPC I, 454a-d y 457a-b), evidenciando, por tanto, la gran cantidad de monedas cluniacenses que con aquella iconología pudieron estar a disposición de los usuarios a partir del periodo que se analiza.

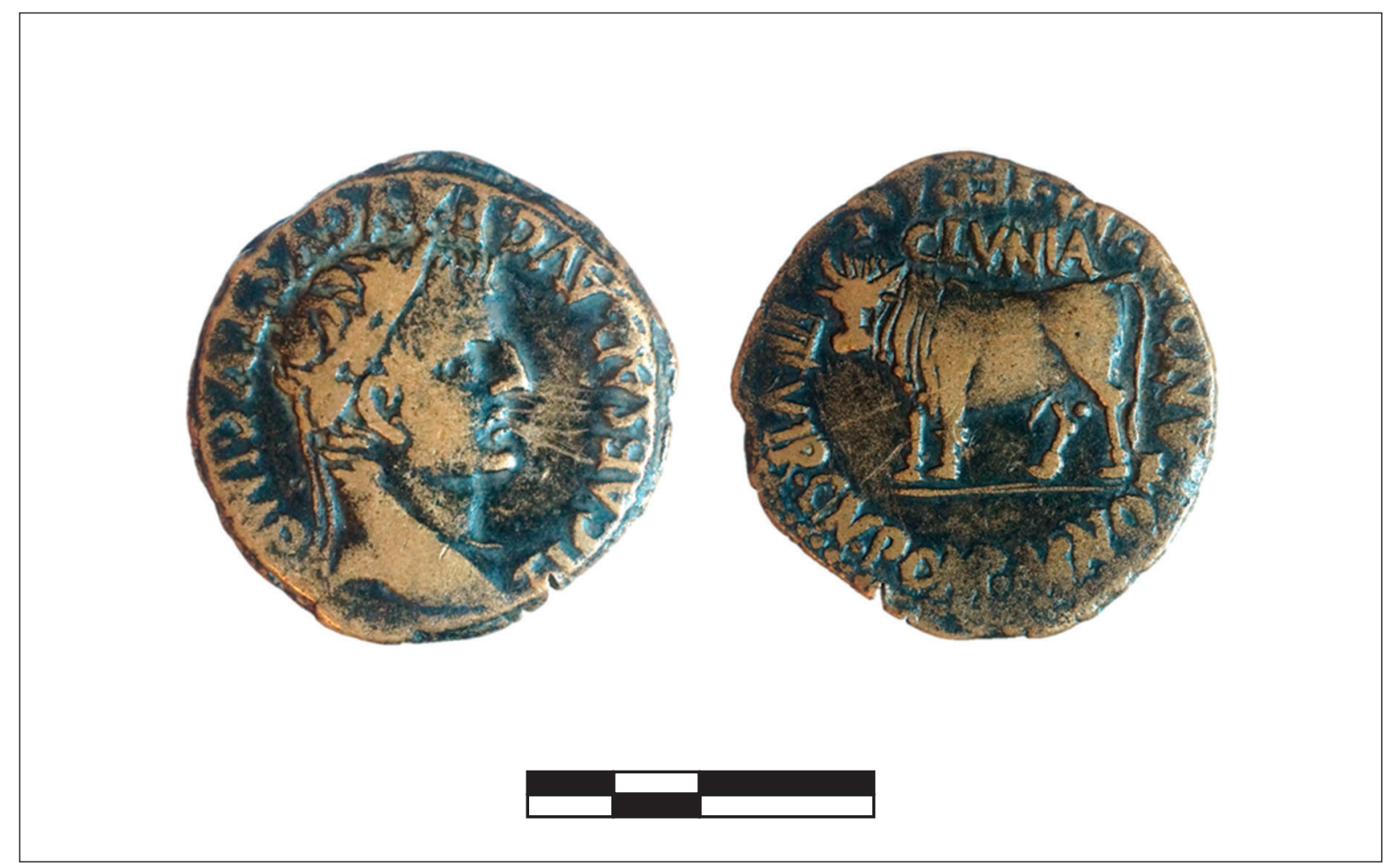

Figura 12

As acuñado en Clunia bajo el imperio de Tiberio (RPC I, 452) (MAN 1993/67/10071)

Continuando la política de selección iconológico-monetaria ya constatada por lo que respecta a la producción de algunos de estos centros en época del Principado, hubo diversas cecas ubicadas en esta región que durante el periodo tiberiano incluyeron la iconología del toro en algunas de las series que fabricaron y que se vincularon con denominaciones distintas a la unidad base. Si en época augustea esta estrategia se coteja en las emisiones de dos municipios alejados el uno del otro, es decir Calagurris (RPC I, 432 y 442) y Ercavica (RPC I, 461), en los años de imperio de Tiberio el fenómeno se desarrolló en tres ciudades distintas concentradas, en este caso, en un territorio bastante circunscrito. Nos referimos, a las cecas de Calagurris (RPC I, 449 y 451), Cascantum (RPC I, 426 y 428) y Graccurris (RPC I, 430); municipios ubicados, como se ha mencionado, en un área de extensión reducida, localizada en la orilla noroccidental del valle del Ebro. 
La tipología de reverso de la totalidad de unidades distintas al as, en este caso concernientes a semises, puestas en circulación por estas ciudades se relacionó con la iconología del toro. En concreto, conforme a los datos conocidos, sabemos que el taller de Graccurris (RPC I, 430) fabricó en estos momentos tan sólo una emisión de semises, mientras que desde Cascantum (RPC I, 426 y 428) y Calagurris (RPC I, 449 y 451) se emitieron dos acuñaciones distintas relativas a aquel valor monetario. La importancia del emblema del toro como representación que simbolizaba la identidad cívica de los habitantes de estos municipios, por tanto, debió ser extraordinariamente notable. Hasta tal punto fue así, que los individuos que autorizaron la fabricación monetaria de aquellos centros decidieron no vincularse con otras iconologías de reverso también de manifiesta simbología cívica, pese a que las autoridades monetarias de Calagurris sí hubieran ordenado grabar una imagen de estas características en los reversos de algunas de las escasas piezas correspondientes a cuadrantes que el centro ordenó acuñar en el periodo anterior (RPC I, 443).

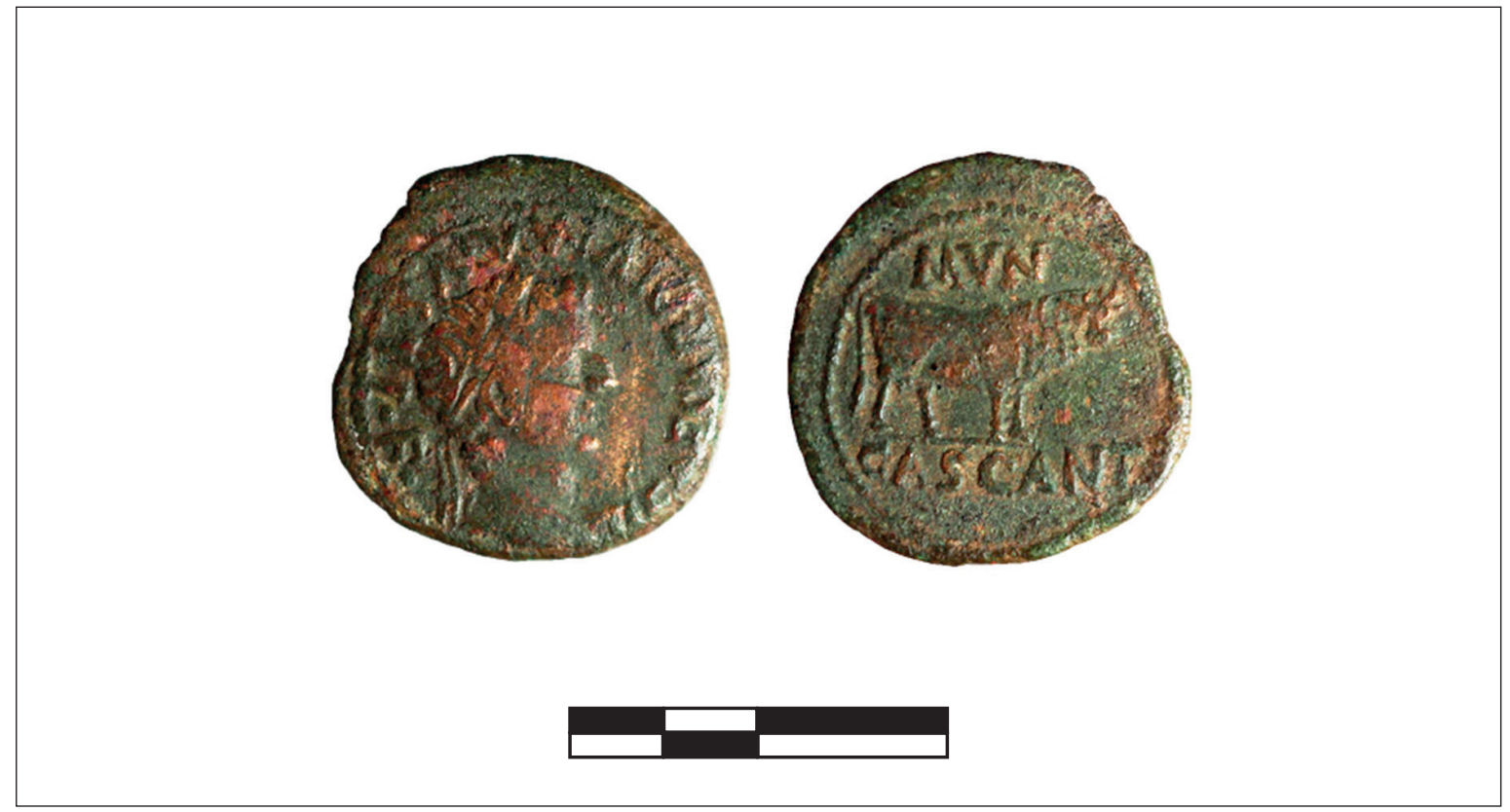

Figura 13

Semis acuñado en Cascantum bajo el imperio de Tiberio (RPC I, 426) (MAN 1993/67/9646)

En cambio, los individuos que durante el imperio de Tiberio ejercieron magistratura en el municipio de Ercavica optaron por abandonar esta estrategia iconológicomonetaria y prefirieron incluir una nueva representación en las monedas divisorias cuya fabricación autorizaron. Nos referimos, en concreto, a la corona cívica; imagen que fue grabada en la única serie de semises que el taller contratado por Ercavica puso en aquellos momentos en disposición de los usuarios (RPC I, 463). Así pues, las series ercavicenses comenzaron en aquella etapa a completar el mensaje cívico-religioso de la iconología del toro con el esencialmente ciudadano-político de la corona cívica, siguiendo una política de selección tipológica indudablemente influida por los modelos 
iconológicos difundidos a través de las emisiones batidas a partir de los años augusteos por los centros más cercanos al propio municipio ${ }^{6} \mathrm{o}$, de las series estatales (RIC I, 40a-b, 57, 75a-b y 77a-b) posiblemente utilizadas en el mismo.

Un fenómeno muy parecido al comentado en el párrafo anterior puede advertirse que ocurrió en lo relativo a la producción de los centros de Lepida-Celsa y Osicerda, cuyas autoridades optaron por dictaminar que se grabara el tipo epigráfico en las escasas monedas divisorias que en estos momentos fabricaron (RPC I, 280 y 469). Esta misma dinámica también puede constatarse que se pudiera desarrollar en Clunia, pues en las 3 series fraccionarias que esta ciudad ordenó fabricar se grabó una imagen totalmente genuina y particular de su producción monetaria. Nos referimos, en concreto, a la figura de un jabalí de cuerpo entero (RPC I, 453, 455 y 458).

Fuera como fuese, desde un punto de vista material, los datos referentes a los valores en los que se adoptó la imagen del toro evidencian la importancia que el icono tuvo para la mayor parte de cecas que decidieron emitir monetario con esta representación. Sin tener en cuenta las propuestas tipológicas caesarausguatanas y turiasoneses, que serán analizadas detenidamente en el siguiente punto del trabajo, se observa como en el resto de ciudades, el icono del toro se concibió como una imagen de naturaleza totalmente emblemática-regional, que, sin duda alguna, identificaba de manera efectiva a aquellos núcleos como centros ubicados en el territorio interior del valle del Ebro. Pero al mismo tiempo, las propias particularidades de cada producción, en este caso, en lo concerniente a la posible selección de otras imágenes para las monedas divisorias, individualizaban las series de cada ceca. Por tanto, las informaciones relativas a distribución por valores de la iconología monetaria del toro, al igual que sugerían los datos analizados en el punto anterior, evidencian como este icono se relacionó en época de Tiberio con dos niveles de proyección emblemática distintos relativos; por una parte, con la identidad local de cada una de las ciudades y, por otra, con la entidad regional de los dos conventii localizados en estos territorios.

\section{LA DIVULGACIÓN DEL ICONO DEL TORO EN ALGUNOS ASES EMITIDOS POR CAESARAUGUSTAY TURIASO}

Aún quedan por detallar las dos ciudades que en estos momentos grabaron la iconología del toro en los reversos de algunas de las series de ases que pusieron en circulación durante el imperio de Tiberio. Uno de estos centros fue la colonia de

\footnotetext{
6 Los propios hallazgos arqueológicos verificados en el yacimiento de Ercavica confirman el uso en la ciudad de un as augusteo acuñado en Bilbilis (RPC I, 395) con corona cívica en reverso (Gomis, 1997a: 103, 105 y 151, n. 14; Gozalbes García, 2018: 221 y 225). Es cierto que este indicio no tiene la suficiente entidad como para sustentar por si sólo una interpretación acerca de la compleja cuestión que se analiza, pues tan sólo se ha atestiguado el hallazgo de un único ejemplar. Por este motivo, no podemos descartar que fuesen otras las piezas que actuaran como prototipos.
} 
Caesaraugusta. Continuando la estrategia iconológico-monetaria que sus magistrados decidieron iniciar ya en época anterior, esta ceca divulgó la representación del toro tan sólo en algunas de las emisiones relativas a la unidad base que durante el lapso tiberiano los artesanos contratados por aquella ciudad fabricaron. Las autoridades del centro optaron por complementar esta iconología de manifiesta simbología cívico-religiosa con otras imágenes relacionas con mensajes de tipo político, militar y religioso vinculados, en la mayor parte de los casos, seguramente también con una narrativa de conmemoración y exaltación sobre la inauguratio colonial y constitución cívica de la ciudad.

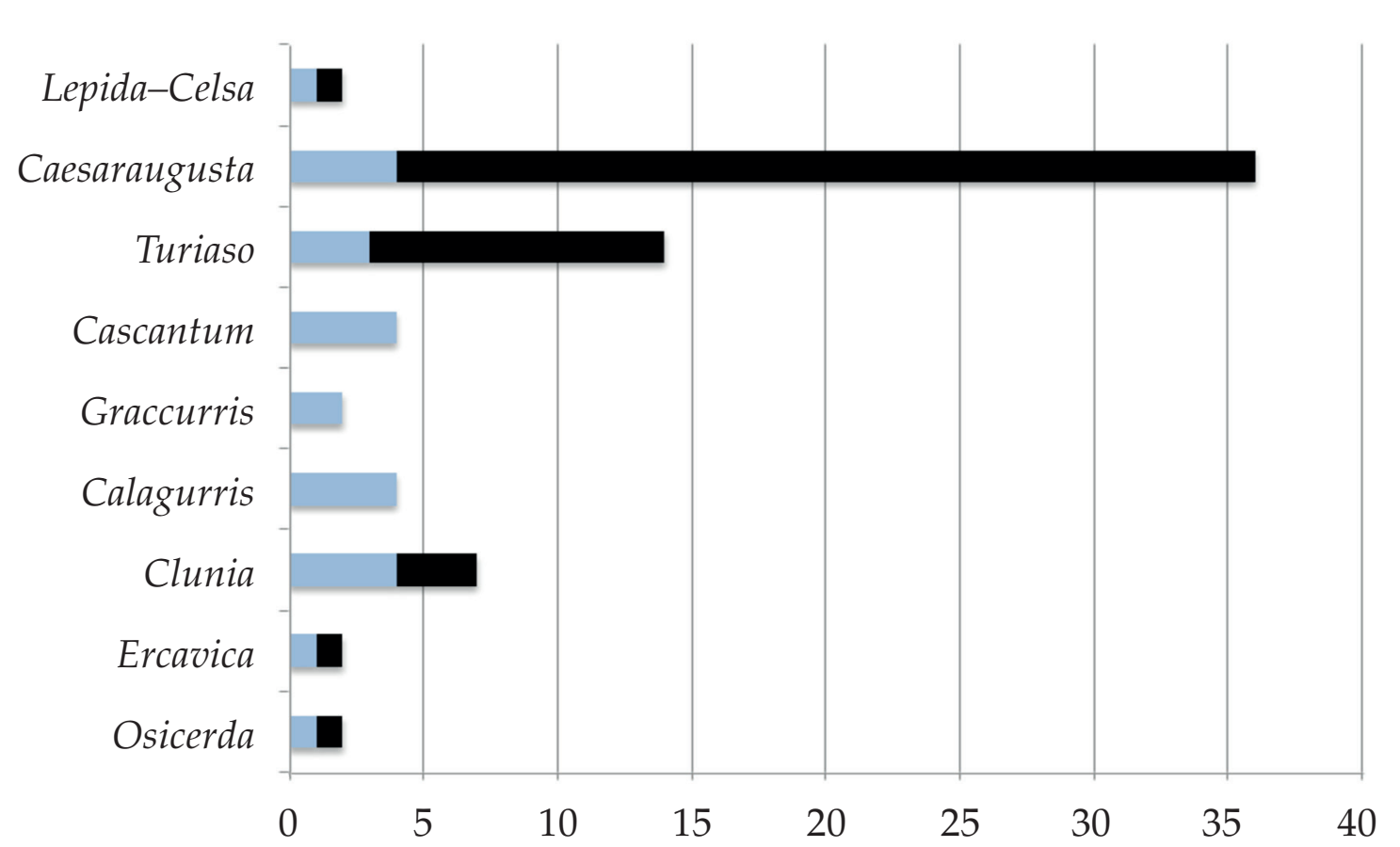

Emisiones con tipo toro en reverso

Emisiones con otras tipologías de reverso

Figura 14

Cálculo de la distribución de piezas con iconología del toro y aquéllas que grabaron otras tipologías de reverso acuñadas en las cecas tiberianas localizadas en la región del valle del Ebro, según centro emisor y número de series fabricadas

Estas representaciones fueron grabadas en ejemplares concernientes a valores monetarios muy diversos (sestercios [RPC I, 344 y 359], dupondios [RPC I, 342, 345348, 360, 363 y 365-366], ases [RPC I, 333, 343, 349-351, 362 y 364], semises [RPC I, 352-356 y 361; RPC S2-I-361A] y cuadrantes [RPC I, 357-358; RPC S-357A]) de tal modo que el propio empleo de los mismos podría haber facilitado que los usuarios pudieran contemplarlos de manera complementaria en los diversos intercambios y atesoramientos que la vida cotidiana de los mismos requería.

Así pues, de las 18 series distintas de ases que la colonia pudo ordenar fabricar en estos momentos del imperio de Tiberio (RPC I, 333-341, 343, 349-351, 362, 364 y 367), 
sus magistrados optaron porque se grabara el icono del toro en 7 de ellas (RPC I, 334337, 339-340 y 367). De entre estas series tan sólo una presentó variantes actualmente dadas a conocer; en este caso, una variación en el modo de exposición de los rótulos de reverso (RPC I, 367a-b). Ciertamente, como se observa, el icono del toro continuó siendo una tipología no exclusiva de las unidades base caesaraugustanas.

No obstante, en claro contraste con lo constatado en época anterior (RPC I, 304310, 314, 317-318, 320, 322 y 327-328), durante los 23 años de duración del imperio de Tiberio, esta imagen se convirtió en la representación de mayor divulgación en las series de ases de nueva acuñación batidas por la ceca, incluso ligeramente por delante de lo contemplado por lo que respecta a las monedas con yunta de bueyes (RPC I, 333, 338 y 349-351; RPC S-333A) (es decir el tipo principal en las monedas acuñadas por la ceca en los años augusteos [RPC I, 306-308, 309, 314, 317-318, 320, 322 y 325; $R P C$ S-308A]). Estos hechos certifican que el icono del toro fue el tipo grabado en las monedas tiberianas acuñadas en Caesaraugusta de más cotidiana utilización y manejo por parte de los usuarios de aquellas inusualmente numerosas piezas en bronce.

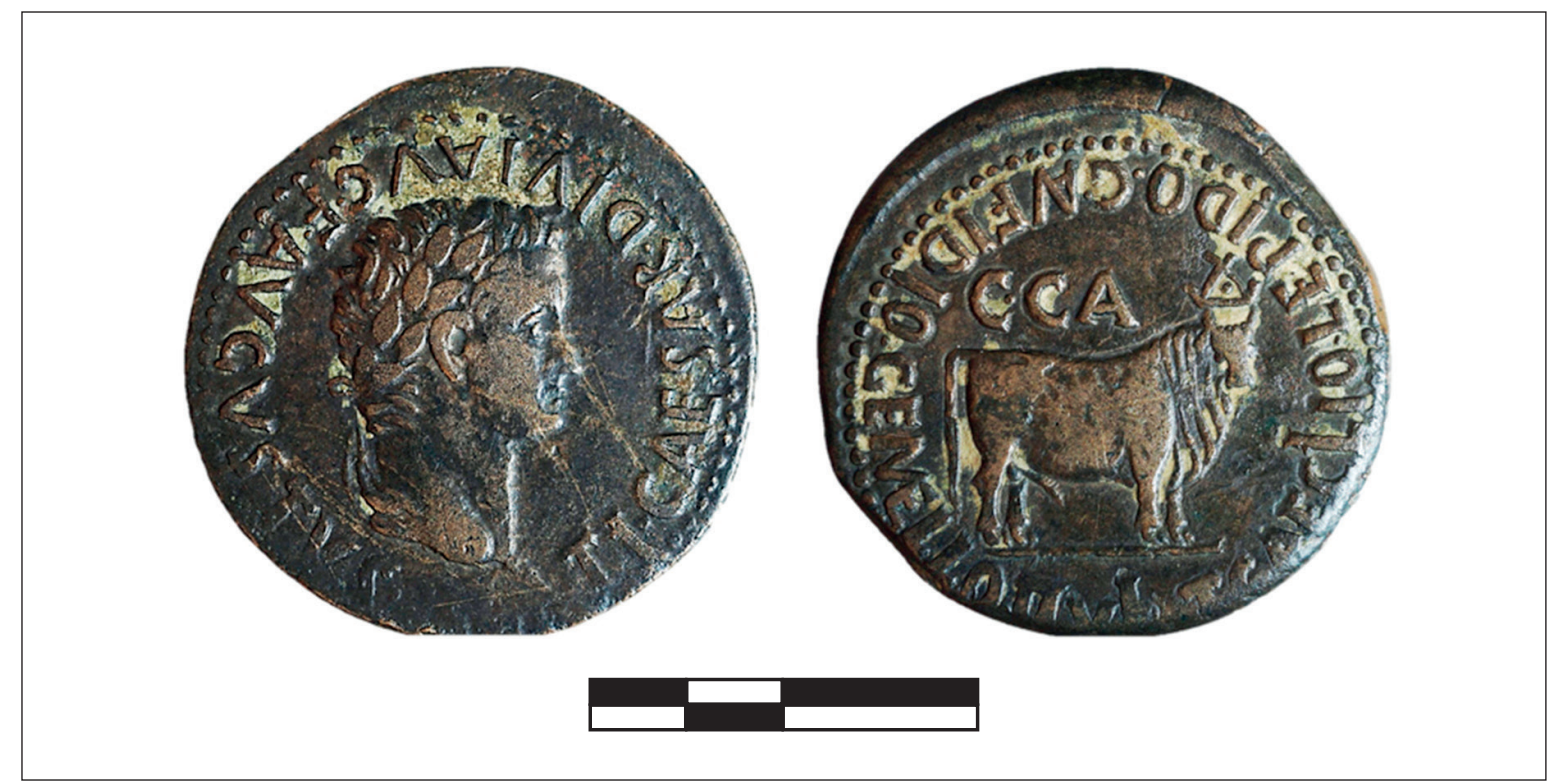

Figura 15

As acuñado en Caesaraugusta bajo el imperio de Tiberio (RPC I, 367b) (MAN 1993/67/8317)

Si atendemos a los datos de emisión teniendo en cuenta las posibles cronológicas específicas de las piezas ${ }^{7}$, que por lo que respecta a la producción cesaraugustana $y$, en claro contraste con el resto de series analizadas en el trabajo, pueden llegar a suponerse de manera bastante aproximada, se advierte como en los primeros años del

\footnotetext{
7 Hemos decidido asumir la propuesta de datación formulada recientemente por A. Aguilera Hernández (Aguilera, 2017), pues consideramos que su razonamiento se ha planteado de manera bastante argumentada.
} 
periodo tiberiano el icono del toro fue el tipo de mayor divulgación en las monedas de nueva acuñación. De las 13 series distintas que pudieron ponerse en uso entre los años 14-30 d. C. (RPC I, 333-344; RPC S-333A), 6 incluyeron la imagen del toro como tipología de reverso (RPC I, 334-337 y 339-340). Es más, si contemplamos las cifras considerando tan sólo los datos referidos al valor base, observamos como durante esta etapa inicial del periodo tiberiano el protagonismo de esta tipología monetaria fue aún mayor, pues en estos instantes se fabricaron 11 acuñaciones relativas a aquella denominación.

En cambio, la imagen de la yunta de bueyes con sacerdote se adoptó tan sólo en 3 series batidas durante estos años, en este caso también relativas a ases ( $R P C$ I, 333 y 338; RPC S-333A). Complementaron esta iconología algunas imágenes relacionadas con la Familia Imperial, que fueron grabadas en dos acuñaciones de ases (RPC I, 341 y 343) y, la representación de un templo tetrástilo que fue cincelada en la única acuñación de sestercios (RPC I, 344) emitida por Caesaraugusta con anterioridad a los años 30 d. C. Por consiguiente, durante esta etapa las monedas caesaraugustanas divulgaron imágenes fundamentalmente religiosas, introduciendo también novedades no atestiguadas en el monetario previo, como eran las representaciones de tipo dinástico.

No sería hasta aproximadamente el comienzo de la década de los años $30 \mathrm{~d}$. C. cuando la divulgación del icono monetario del toro comenzó a disminuir en las series de nueva acuñación caesaraugustanas, hasta el punto de que a partir de entonces tan sólo se fabricó una serie recogiendo aquella tipología monetaria (RPC I, 367). En este sentido, dados los volúmenes de emisión de la ceca, que en lo concerniente a estos últimos años tiberianos fueron bastante altos (RPC I, 345- 367; RPC S-357A; RPC S2-I361A), suponemos que el descenso en la cifra de monedas acuñadas por Caesaraugusta con iconología taurina debió ser altamente llamativo para los habitantes de la ciudad, sobre todo si tenemos en cuenta que durante el breve lapso de gobierno de Calígula la colonia no batió ninguna pieza recogiendo aquella tipología monetaria.

Ahora bien, esta reducción coincidió con los momentos de mayor fabricación de denominaciones distintas al as (sobre todo de dupondios [RPC I, 345-348, 360, 363 y 365-366; RPC S-357A; RPC S2-I-361A]) es decir de valores en los que los magistrados caesaraugustanos decidieron no incluir la representación objeto de estudio. Por tanto, es de prever que el desinterés por la imagen pudiera deberse también a una especial dinámica de producción mayoritaria de denominaciones diversas, especialmente de aquellas de alto valor. Y, por otra parte, también resulta evidente que los ases acuñados con anterioridad siguieron en la circulación, de modo que los receptores de aquellas piezas continuaron utilizando monedas que conectaban el retrato de Tiberio con la iconología del toro.

Entre estas representaciones de significativa divulgación a partir de los años 30 d. C., es precioso destacar aquellas relacionadas con iconos de alusión político-ciudadana, como fueron la corona cívica y el tipo epigráfico. Estas tipologías ya habían sido adoptadas en diversas acuñaciones de divisores puestas en uso en época del Principado (RPC I, 312-313, 316, 324 y 332; RPC S2-I-329A), pese a lo cual su difusión no se 
atestigua en las emisiones batidas a principios del periodo tiberiano. Fue a partir de los años $30 \mathrm{~d}$. C. cuando estas imágenes volvieron a notar un gran incremento, siendo adoptadas sobre todo en piezas relativas a denominaciones de alto valor. Así pues, la corona cívica fue grabada en 2 de las numerosas emisiones de dupondios batidas durante aquellos años (RPC I, 347-348). El tipo epigráfico experimentó una mayor difusión, pues fue incluido en 4 series de dupondios (RPC I, 360, 363 y 365-366), 2 acuñaciones de semises (RPC I, 361; RPC S2-I-361A) y una emisión de sestercios (RPC I, 359) puestos en uso por Caesaraugusta en aquellos años.

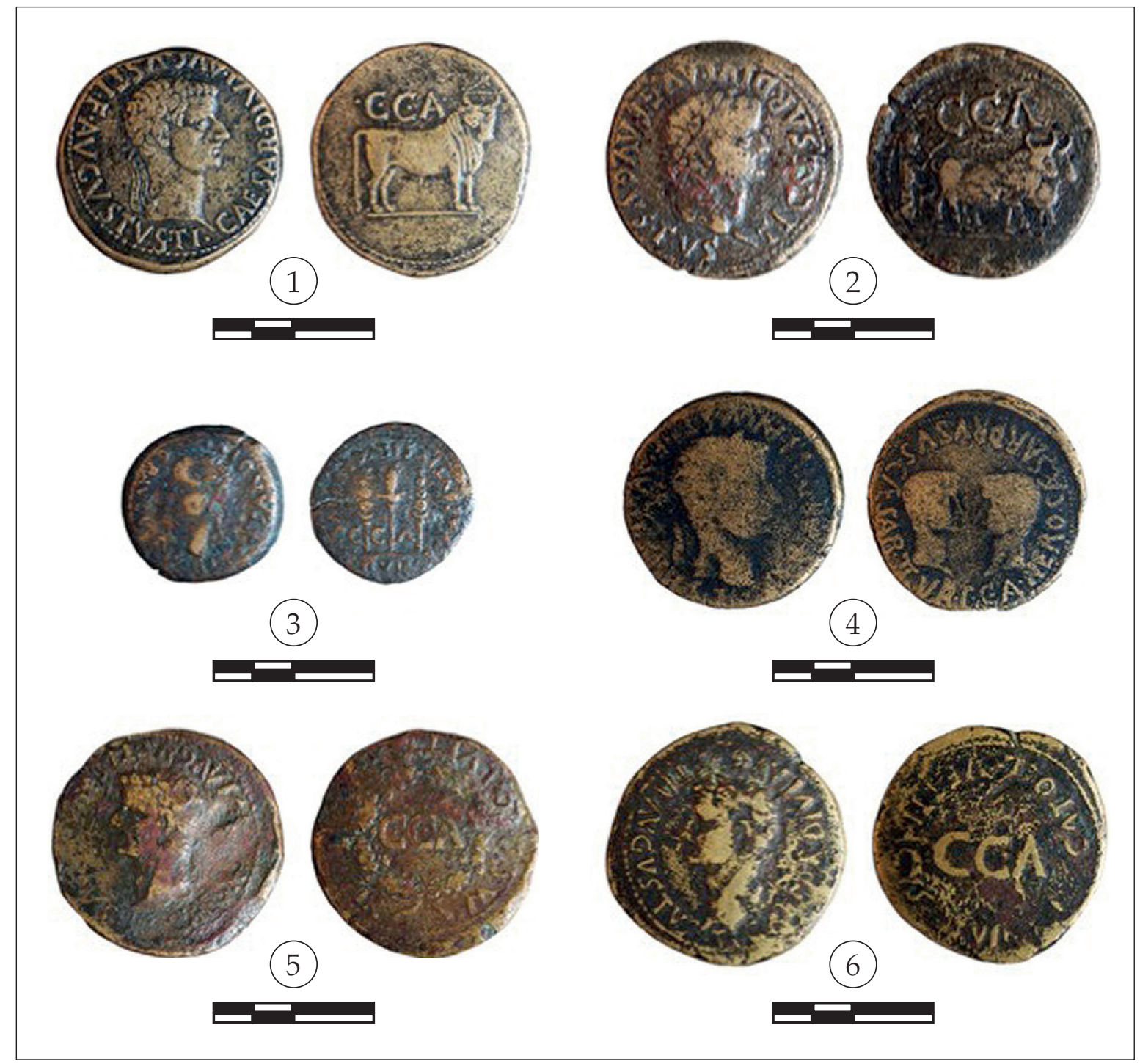

Figura 16

Producción tiberiana de Caesaraugusta

1: As acuñado en Caesaraugusta bajo el imperio de Tiberio (RPC I, 340) (MAN 1993/67/8210)

2: As acuñado en Caesaraugusta bajo el imperio de Tiberio (RPC I, 333) (MAN 1993/67/8198)

3: Semis acuñado en Caesaraugusta bajo el imperio de Tiberio (RPC I, 353) (MAN 1993/67/8227)

4: As acuñado en Caesaraugusta bajo el imperio de Tiberio (RPC I, 343) (MAN 1993/67/8297)

5: Dupondio acuñado en Caesaraugusta bajo el imperio de Tiberio (RPC I, 347) (MAN 1993/67/8276)

6: Dupondio acuñado en Caesaraugusta bajo el imperio de Tiberio (RPC I, 348) (MAN 1993/67/8278) 
Los iconos de alusión cívico-militar, cuya propaganda no se atestigua en los ejemplares fabricados en los primeros momentos de imperio de Tiberio, también notaron un gran auge en las piezas caesaraugustanas acuñadas a partir del año $30 \mathrm{~d}$. C., hasta el punto de que en los últimos momentos de este periodo se convirtieron en las imágenes monetarias de mayor difusión (Aguilera, 2017: 93). En contraste con lo que puede constarse en época augustea, cuando estas representaciones se adoptaron sobre todo en monedas relativas a semises (RPC I, 311, 315, 321 y 323), en aquellos años del periodo tiberiano estas imágenes se incluyeron en valores diversos: dos emisiones de dupondios (RPC I, 345-346), una única acuñación de ases (RPC I, 364), 5 series de semises (RPC I, 352-356) y 3 de cuadrantes (RPC I, 357-358; RPC S-357A).

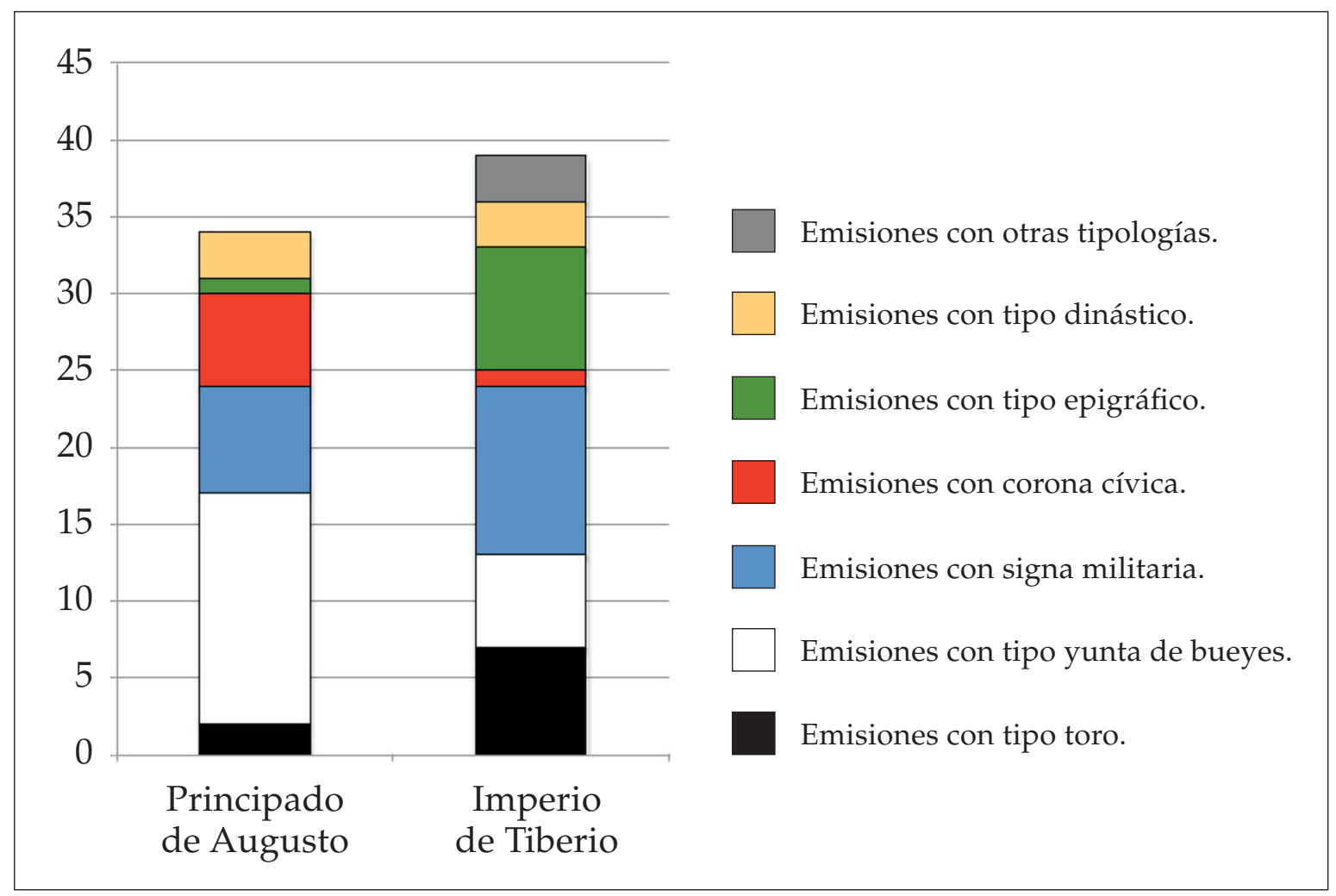

Figura 17

Cálculo de la distribución de las distintas iconologías distintas al retrato imperial grabadas en el monetario caesaraugustano, según periodo de fabricación de las distintas emisiones y número de series batidas

Complementaban estas iconologías otros tipos vinculados a una clara alusión de tipo religioso-cívico, como eran la yunta de bueyes, seleccionada para su adopción en 3 series distintas de ases acuñados a partir del año 30 d. C. (RPC I, 349-351) o la imagen de un templo tetrástilo (RPC I, 362). Por último, podemos aludir a que dos de las acuñaciones ya citadas recogieron como figura de anverso la imagen de la alegoría Pietas (RPC I, 362-363) y otras dos la representación a partir de varias iconografías del propio Tiberio de cuerpo entero (RPC I, 345-346). Por tanto, durante estos últimos años del periodo tiberiano se fabricaron monedas divulgando tipologías excepcional- 
mente diversas, adoptando en la mayor parte de los casos imágenes influidas por tipos proyectados previamente a partir de las series de fábrica estatal (Aguilera, 2017).

Pese a que en época del Principado no existió una producción monetaria que divulgara un programa iconológico tan heterogéneo como el caesaraugustano, al menos incluyendo la iconología del toro como tipo monetario, en tiempos de Tiberio sí hemos podido constatar la puesta en circulación de algunas series similares acuñadas por otra ceca distinta ubicada en la región que analizamos. Nos referimos, en efecto, al municipio de Turiaso.

Y es que este centro, situado en una zona bastante cercana a la propia colonia caesaraugustana, puso en circulación 5 emisiones distintas de ases tiberianos (RPC I, 413, 417-419 y 423) adoptando la representación objeto de estudio tan solo en 3 de ellas (RPC I, 417-419) y complementando esta imagen con otras diversas tipologías de reverso. Estos tipos se grabaron también en las series relativas a otras especies monetarias (cuadrantes [RPC S-421A], semises [RPC I, 414-416, 420-421 y 424], ases [RPC I, 413 y 423] y sestercios [RPC I, 422]). Cada una de estas 3 acuñaciones de ases con tipo toro en reverso presentaron una variante actualmente conocida (RPC I, 417a-b, 418a-b y 419a-b) y, por consiguiente, intuimos que, pese a todo, el número de monedas turiasoneses que divulgaron esta iconología fueron bastante numerosas.

Aunque la iconografía específica de la representación del toro en las monedas tiberianas batidas por orden de los magistrados de Turiaso fue distinta a la divulgada en las piezas caesaraugustanas, nosotros somos de la opinión de que la proyección iconológica relacionada con esta imagen pudo presentar aspectos en parte similares en las producciones de ambas ciudades. Con todo, en los ejemplares emitidos en estos momentos del imperio de Tiberio por Caesaraugusta y Turiaso se divulgaron imágenes muy diversas, incluyendo, además del icono taurino, la corona cívica ( $R P C$ I, 347 y 413-415) y el tipo epigráfico (RPC I, 348, 359-361, 363, 365-366 y 420-421; RPC S-421A; RPC S2-I-361A), algunas otras figuras de influencia metropolitana no presentes en el monetario acuñado por el resto de centros ubicados en la región.

En concreto, entre las imágenes distintas a las del bóvido grabadas en las piezas tiberianas producidas por Turiaso se encontraba la representación figurada a partir de distintas iconografías del propio Augusto divinizado (Amela, 2016: 62). Esta especial iconología referente a la deidad del princeps se grabó en algunas series de semises (RPC I, 424), ases (RPC I, 423) y sestercios (RPC I, 422) batidos por mandato del municipio durante los años inmediatamente posteriores a la muerte del que fuera primer emperador de Roma. Según han destacado algunos investigadores aquellas series debieron ser altamente llamativas dado que presentaron una gran calidad en el grabado de los propios tipos (Amela, 2016: 62; Ripollès, 2010: 241). Estas circunstancias evidencian el notable interés que pudieron tener los magistrados monetarios de la ciudad por que este icono se difundiera a partir del empleo de piezas de distinto valor, en cuya fabricación pudieron emplearse cospeles de gran calidad y punzones detenidamente trabajados. 
Estas figuras que representaban al emperador divinizado eran bastante reconocibles, pues además fueron identificadas a partir de la información contenida en las propias leyendas que las acompañaban, las cuales incluían asimismo abreviaturas referentes al nombre del centro que había fabricado estas especiales monedas y al status municipal del mismo. Por tanto, la ceca de emisión pudo ser fácilmente identificada por los usuarios de las piezas, quienes seguramente pudieron acostumbrarse a aquellas leyendas dado, que fueron también divulgadas en el resto del monetario acuñado por la ciudad.

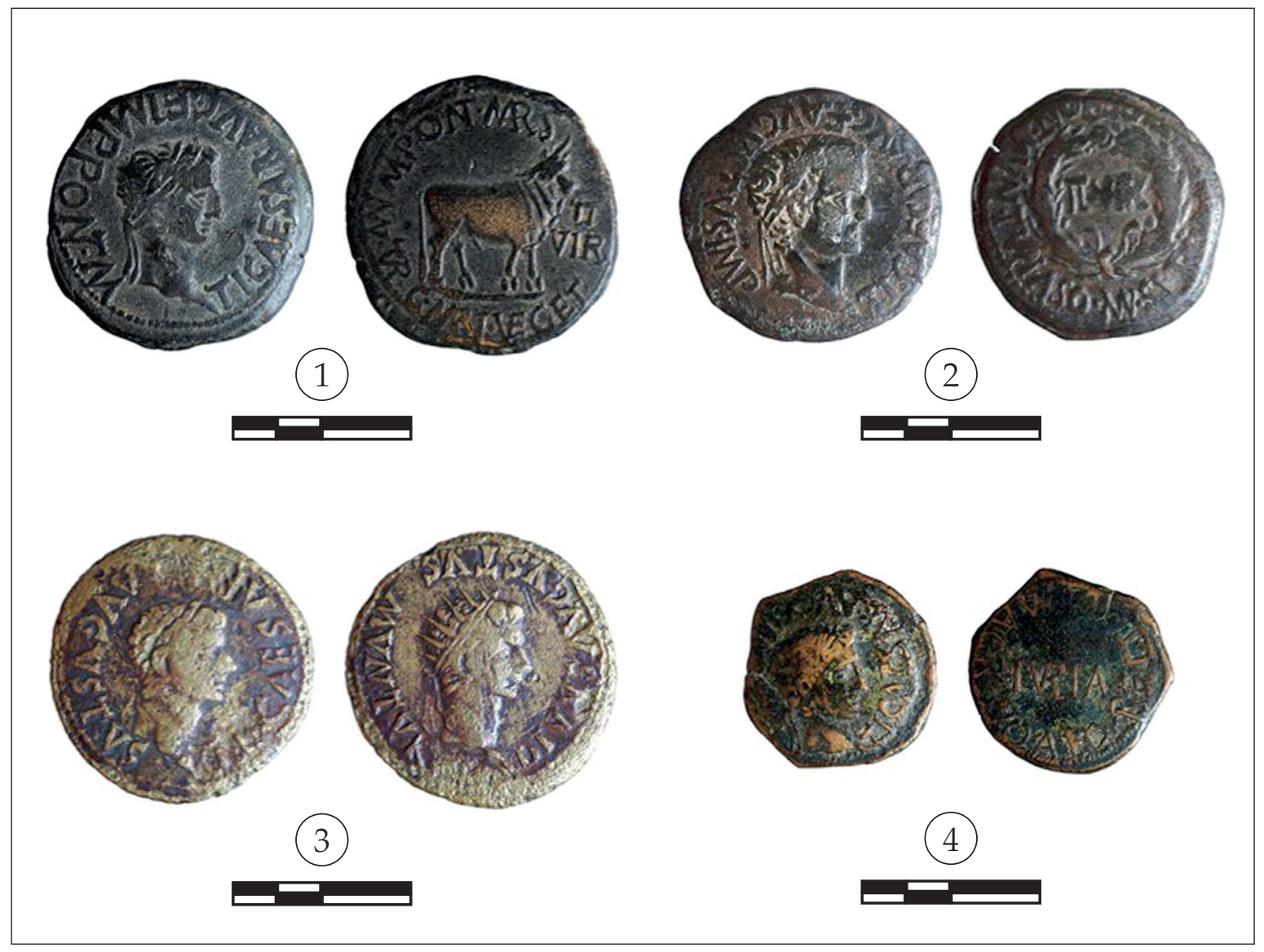

Figura 18

Producción tiberiana de Turiaso

1. As acuñado en Turiaso bajo el imperio de Tiberio (RPC I, 518a) (MAN 1993/67/13022)

2: As acuñado en Turiaso bajo el imperio de Tiberio (RPC I, 413) (MAN 1993/67/12969)

3: As acuñado en Turiaso bajo el imperio de Tiberio (RPC I, 423a) (MAN 1993/67/12948)

4: Semis acuñado en Turiaso bajo el imperio de Tiberio (RPC I, 420) (MAN 1993/67/13127)

Todos estos datos sugieren que las diversas representaciones monetarias caesaraugustanas y turiasonenses se relacionaban con un imaginario particular, que no puede ponerse en relación completamente directa con la emblemática monetaria regional atestiguada en el resto de cecas cercanas, y que se basaba en la definición de una proyección local adaptada tanto a los principales parámetros iconológicos del 
territorio como también a la ideología provincial romana. Aunque los magistrados de Caesaraugusta y Turiaso se vincularon con una estrategia en algunos aspectos relacionada con la política monetario-representativa del territorio, pues decidieron incluir el icono del toro en algunos de los numerosos ases cuya fabricación sancionaron, al mismo tiempo lograron adaptar la divulgación de esta imagen y de su general alusión simbólica a una propaganda cívica mucho más cercana al imaginario metropolitano (también relacionado con las acuñaciones de la capital provincial, Tarraco [RPC I, 218233]) que al propiamente regional. Además, en ambos casos, el mensaje cívico-religioso del icono fue extensamente complementado por el resto de monedas acuñadas, de modo que puede intuirse que esta específica narración se acentuó de manera mucho más clara en las series acuñadas por Caesaraugusta y Turiaso que en las emitidas por el resto de cecas del territorio, en cuyas producciones, como venimos sosteniendo, se enfatizó sobre todo los aspectos relacionados con la emblemática regional.

\section{CONCLUSIONES:}

El detenido análisis del monetario con toro acuñado durante los años de gobierno de Tiberio por las cecas ubicadas en la región interior del valle del Ebro plantea que el proceso de divulgación del icono fue ya en esta época general, pero bastante heterogéneo. El proceso desarrollado en cada centro fue notablemente particular, puesto que cada ceca adaptó esta iconología a un programa iconográfico y epigráfico propio, completando el simbolismo de la imagen con otros iconos presentes en el resto de monedas acuñadas por dichas ciudades.

La iconología monetaria del toro difundida por las cecas ubicadas en la región interior del valle del Ebro se relacionó con tres imágenes distintas, las cuales, pese a las diferencias iconográficas, se vincularon en todos los casos a una misma proyección simbólica. La maduración de esta iconología y su general difusión en la región provocó que el simbolismo relacionado con la misma remitiera a dos mensajes distintos que se acentuaron de manera desigual en unos cecas y otras.

En primer lugar, es evidente que el icono se relacionaba con una alusión cívicoreligiosa, y en ocasiones militar, relativa a las ceremonias que se habrían celebrado en el contexto de promoción colonial y/o municipal de aquellos centros. Los tipos presentes en el resto del monetario acuñados por aquéllos completaron en algunos casos esta narrativa visual. Es cierto que en la mayor parte de las ciudades la propaganda monetaria estuvo ligada a un protagonismo bastante evidente de la iconología taurina; incluso algunas cecas decidieron no divulgar otras tipologías de reverso. No obstante, pese a ello, hubo dos ciudades que presentaron una propuesta tipológico-monetaria distinta, pues incluyeron numerosas imágenes también estrechamente vinculadas con aquel relato cívico-religioso relativo al episodio fundacional y de constitución cívica de un determinado municipio y/o colonia. 
En segundo lugar, el icono del toro se presento también como un símbolo de naturaleza fundamentalmente emblemático-regional, que una vez madurado y con sus propias características podría haber conectado con el antiguo hábito de homogeneidad iconológico-monetaria verificado en las acuñaciones indígenas fabricadas por los centros de la región. Ahora bien, pese a que los datos evidencian que hubo un nivel de emblemática general relacionado con la iconología monetaria del toro que debió afectar a todas las ciudades, cada una de ellas intentó definirse de una manera visiblemente particular. Así pues, desde un punto de vista simbólico estas circunstancias nos permiten concluir que en época tiberiana los niveles de proyección identitaria relacionados con aquella emblemática en la región del valle del Ebro fueron totalmente duales e incidieron en las producciones de los centros de manera desigual:

-En primer lugar, puede percibirse un evidente nivel regional, vinculado a la propia iconología taurina y a la simbología relacionada con la misma.

-En segundo lugar, puede también observarse un nivel de irradiación de la identidad de tipo local que estuvo relacionado con los distintos programas iconográficos y epigráficos y, sobre todo con la presencia o no de otro tipo de imágenes en el monetario acuñado por las diversas cecas.

\section{AGRADECIMIENTOS:}

Nuestro trabajo se ha elaborado en el marco del Proyecto de Investigación «La iconografía monetaria del toro como fuente de identidad provincial en la región del valle del Ebro durante la etapa julio-claudia», co-dirigido por el Prof. Dr. Á. Padilla y Dña. H. Gozalbes y, financiado por el Vicerrectorado de Investigación y Transferencia de la Universidad de Granada (2018-2019). A su vez nuestro estudio se enmarca en el proyecto doctoral «Tradición indígena y modelos romanos en las acuñaciones provinciales de la Hispania antigua» inserto dentro del Programa de Doctorado en «Historia y Artes» de la Universidad de Granada, financiado también por un contrato-beca FPU del Vicerrectorado de Investigación y Transferencia de la Universidad de Granada (2015-2019) y dirigido por el Prof. Dr. A. Padilla. Agradezco sus constantes consejos y correcciones, así como el inestimable apoyo que viene prestando a lo largo de la investigación que ha dado lugar a la presente contribución. Igualmente, el estudio del material que presentamos forma parte de una investigación mucho más amplia centrada en el análisis de la moneda provincial hispana depositada en el Museo Arqueológico Nacional de Madrid y realizada durante una estancia que se desarrolló entre los meses de febrero y julio de 2015 en el Instituto Arqueológico Alemán de Madrid, bajo la tutoría de la Profa. D. Marzoli. Agradezco enormemente la ayuda prestada por la mencionada profesora, así como también a M. Cruz, P. Grañeda y P. Otero, conservadoras del Departamento de Numismática del citado museo por el permiso y las facilidades procuradas durante el estudio. 


\section{REFERENCIAS BIBLIOGRÁFICAS}

ABASCAL, J. M., ALBEROLA, A. y CEBRIÁN, R. (2008): Segobriga IV. Hallazgos monetarios, Madrid.

ABASCAL, J. M. y ESPINOSA, U. (1989): La ciudad hispano-romana: privilegio y poder, Logroño.

AGUILERA, A. (2014): «La iconografía de la yunta fundacional en el contexto hispano: los casos de las colonias de Lepida, Augusta Emerita y Caesar Augusta», Nvmisma n. 258, 95 129.

- (2015): Imágenes para una nueva Roma: iconografía monetal de la colonia Caesar augusta en el periodo Julio Claudio, Tesis doctoral inédita, Universidad de Zaragoza.

- (2017): Imágenes para una nueva Roma: iconografía monetal de la colonia Caesar Augusta en el periodo julio-claudio, Zaragoza.

ALFÖNDY, G. (1987): Römisches Städtewesen auf der neu kastilischen Hochebene. Ein Testfall für die Romanisiercrung, Heilderlberg.

AMANDRY, M., BURNETT, A., CARRADICE, I., RIPOLLÈS, P. P. \& SPOERRY, M. (2014): Roman Provincial Coinage. Supplement 3, New York (citado como RPC S3).

AMANDRY, M., BURNETT, A., HOSTEIN, A. MAIRAT, J. RIPOLLÈS, P. P. \& SPOERRY, M. (2017): Roman Provincial Coinage. Supplement 4, en red (citado como RPC S3).

- (2019): Roman Provincial Coinage. Supplement 5, en red (citado como RPC S5).

AMELA, L. (2000): «Colonias y municipios cesarianos de la provincia Hispania Citerior», Anuari de filología. Secció D, Studia graeca et latina n. 10, 7-34.

- (2001-2002): «La Colonia Victrix Iulia Lépida», Kalathos n. 20-21, 239-249.

- (2004): «La acuñación bilingüe de Kelse/Cel(sa)», Habis n. 3, 207-217.

- (2012a): «De nuevo sobre la acuñación binlingüe de Kelse/CEL(sa)», Gaceta Numismática n. $184,31-52$.

- (2012b): «Las dos primeras emisiones latinas de la ciudad de Calagurris», Kalakoricos n. 17, 127-146.

- (2016): «Turiaso: sus monedas augusteas y tiberianas», Hécate n. 3, 55-78.

- (2018): El Segundo Triunvirato en Hispania. Fuentes literarias y numismáticas. Tesis Doctoral Inédita Universidad de Castilla-La Mancha, Cuenca.

ANDRES HURTADO, G. (2002): «Municipium Calagurris Iulia Nassica», Kalakorikos n. 7, 51-78.

BARCELÓ, P. y FERRER, J. J. (2007): Historia de la Hispania romana, Madrid.

BARRANDON, N. (2011): De la pacificación à lintégration des Hispaniques (133-27 a. C.). Les mútations des societés indigènes d'Hispanie centrale et septentrionale sous domination romaine, Bordeaux.

- (2014): «Les oubliés des promotions de la fin de la République en Hispanie Citérieure: les cités de droit pérégrin (état de la question)», Veleia n. 31, 33-52. 
BELTRÁN LLORIS, F. (1978): «Los magistrados monetales en Hispania», Nvmisma n. 150-155, 169-211.

- (1980): Epigrafia latina de Saguntum y su territorio, Valencia.

- (1996): «Una liberalidad la Pubela de Híjar (Teruel) y la localización del municipium de Osicerda», Archivo Español de Arqueología n. 173-174, 287-294.

- (2000): «El tiempo de Augusto», Roma en la Cuenca Media del Ebro. La Romanización en Aragón, 73-93. Zaragoza.

- (2002): «Identidad cívica y adhesión al príncipe en las monedas municipales hispanas», F. Marco, F. Pina y J. Remesal (eds.): Religión y propaganda política en el mundo romano, 159-187. Barcelona.

- (2004): «Sobre la localización de Damania, Leonica, Osicerda y Orosis», Palaohispanica n. 4, 67-88.

- (2017): «Augusto y el valle medio del Ebro», Gerión n. 35, 525-540.

BELTRÁN LLORIS, F. y BELTRÁN LLORIS, M. (1980): «Numismática hispanorromana de la Tarraconense», Nvmisma n. 162-164, 107-127.

BELTRÁN LLORIS, F. y MOSTALAC, A. (2008): «La Colonia Lepida/Celsa y Saldvie: sus testimonios arqueológicos durante el segundo triunvirato y comienzos del Imperio», M. P. García-Bellido, A. Mostalac. y A. Jiménez, (eds.): Del imperium de Pompeyo a la auctoritas de Augusto. Homenaje a Michael Grant, 107-127. Madrid.

BELTRÁN LLORIS, M.(2002): «Turiaso. La ciudad romana», Caesaraugusta n. 76, 23-31.

BELTRÁN LLORIS, M., MOSTALAC, A. y LASHERAS, J. A. (1984): Colonia Victrix Ivlia LepidaCelsa (Velilla del Ebro, Zaragoza). 1. La arquitectura de la «Casa de los delfines», Zaragoza.

BELTRÁN LLORIS, M. y PAZ PERALTA, J. Á. (2014): «Mitos y cultos relacionados con el toro en Caesar Augusta y su convento jurídico durante la Antigüedad», El Coso de la Misericordia de Zaragoza (1764-2014), 11-22. Zaragoza.

BELTRÁN LLORIS, M. PAZ, J. y ROYO, J. (1989: «Las excavaciones del Museo Provincial de Zaragoza en el Municipium Tvriaso (Tarazona, Zaragoza)», Caesaraugusta n. 51-52, 117-120.

BELTRÁN MARTÍNEZ, A. (1984): «Numismática antigua en el área de Calahorra», Calahorra, bimilenario de su fundación. Actas del I Simposium de historia de Calahorra, 53-67. Madrid.

- (2002): «Aragón hace dos mil años», Revista C. E, C, E, L n. 2, 41-72.

BELTRÁN VILLAGRASA, P. (1972): «La cronología del poblado ibérico del Cabezo de Alcalá (Azaila), según las monedas allí aparecidas», Obra completa, I. Antigüedad, 159-209. Zaragoza.

BLÁZQUEZ J. M. (1962): Religiones primitivas de Hispania. Fuentes literarias y epigráficas, Roma.

BLÁZQUEZ CERRATO, C. (2008): «Emisiones y circulación monetaria en Hispania en época transicional (72-27 a. C.)», M. P. García-Bellido, A. Mostalac, A. Jiménez (eds.): Del imperium de Pompeyo a la auctoritas de Augusto. Homenaje a Michael Grant, 259-278. Madrid. 
BRAVO, G. (2007): Hispania y el Imperio, Madrid.

BURILLO MOZOTA, F. (2002): «Etnias y ciudades estado en el valle medio del Ebro, el caso de Kalakorikos/Calagurris Nassica», Kalakorikos n. 7, 9-30.

BURNETT, A., AMANDRY, M. \& RIPOLLÈS, P. P. (1992): Roman provincial coinage, vol. I. From the death of Caesar to the death of Vitellius (44 BC-AD 69), London-Paris (citado como RPC).

- (1998): Roman Provincial Coinage. Supplement 1, London (citado como RPC S).

BURNETT, A. M, AMANDRY, M., RIPOLLÈS, P. P. \& CARRADICE, I. (2006): Roman Provincial Coinage. Supplement 2, Valencia (citado como RPC S2-I).

CHAVES, F. (1998): «Monedas para una sociedad nueva», Hispania. El legado de Roma. En el año de Trajano (La Lonja-Zaragoza, Septiembre-Noviembre de 1998), 83-93. Zaragoza.

CHAVES, F. y MARTÍN, M. C., 1993, El elemento religioso en la amonedación hispana antigua, en Actes du Xième Congrès International de Numismatique, 666-668. Louvain/Luxemburgo.

CURCHIN, L. A. (2004): The Romanization of Central Spain. Complexity, diversity and change in a provincial hinterland, London/New York.

DE PALOL, P. (1994): Clunia: historia de la ciudad y guía de las excavaciones, Burgos.

DOMINGUEZ, A. y AGUILERA, A. (2009): «Caesaraugusta a la luz de los últimos descubrimientos. Consideraciones en torno al áureo de Mars Ultor», A. Arévalo (coord.): Actas del XIII Congreso Nacional de Numismática «Moneda y Arqueología», vol. I, 455-472. Madrid.

- (2011-2012): «Caesar Augusta en imágenes: la colección de monedas del Museo de Zaragoza», Acta Numismática n. 41/42, 63-84.

- (2012): «Ritus sagrats i sacerdots», M. Campo et al. (eds.): Déus i mites de l'antiguitat. L'evidencia de la moneda d'Hispània, 72-77. Barcelona.

ESPINOSA, U. (1984): Calagurris Iulia, Calahorra.

- (2011): «Edad antigua. La ceca latina del Municipio Calagvrris Ivlia», Historia de Calahorra (Calahorra), 88-93. Calahorra.

FARIA, A. M.(2007): «[Recensión de] Burnett, A. M., Amandry, M., Ripollès, P. P. y Carrice, I. Roman Proᄀvincial Coinage. Supplement 2», Revista Portuguesa de Arqueología n. 10.2, 305-315.

GARCÍA-BELLIDO, M. P. (2003): «La historia de la colonia Lepida-Celsa según sus documentos numismáticos: su ceca imperial», Archivo Español de Arqueología n. 187-188, 273-290.

- (2004): Las legiones hispánicas en Germania. Moneda y ejército, Madrid.

- (2006a): «Ejército, moneda y política económica», GARCÍA-BELLIDO, M. P. (coord.): Los campamentos romanos en Hispania (27 a. C.- 192 d. C.). El abastecimiento de moneda, vol. I, 673-706. Madrid.

- (2006b): «El abastecimiento de moneda al ejército hispánico durante las guerras cántabras», MORILLO, A. (ed.): Arqueología militar romana en Hispana II. Producción y abastecimiento en el ámbito militar, 219-239. León 
GARCÍA-BELLIDO, M. P. y BLÁZQUEZ CERRATO, C. (1995): «Formas y usos de las magistraturas en las monedas hispánicas», GARCÍA-BELLIDO, M. P. y SOBRAL CENTENO, R. M. (eds.): La moneda Hispánica. Ciudad y Territorio. Actas del I Encuentro Peninsular de Numismática Antigua (Madrid, noviembre 1994), 381-428, Madrid.

- (2001): Diccionario de cecas y pueblos hispánicos, Madrid.

GARCÍA-GELABERT PÉREZ, M. P. y BLÁZQUEZ MARTÍNEZ, J. M. (1997): «Carácter sacro y funerario del toro en el mundo ibérico», Quaderns de prehistòria i arqueología de Castelló n. $17,417-442$.

GARCÍA SERRANO, J. A. (2003-2004): «Turiaso-Turiazu. ¿Dónde está la ciudad celtibérica?», Turiaso n. XVII, 119-133.

GALSTERER, H. (1971): Untersuchengen zum römischen Städtewesen auf der Iberischen Halbinsel, Berlin.

GÓMEZ BARREIRO, M. (2008): «Historia de la investigación sobre la ceca de Caesaraugusta», Nvmisma n. $252,83-120$.

- (2017): La moneda de Caesaraugusta. Producción y circulación monetaria, Madrid.

GÓMEZ-PANTOJA, J.(1994): «Germánico y Caesaraugusta», Polis n. 6, 169-202.

GOMIS, M. (1996): «Osicerda: un ejemplo de acuñaciones hispano-romanas en época de Tibero», Gaceta Numismática n. 122 , 29-46.

- (1997 a): La ceca de Ercavica, Barcelona-Madrid.

- (1997 b): «Augusto: el nacimiento de un nuevo lenguaje iconográfico», La moneda en temps d'August. Curs d'Història monetària d'Hispània (13 i 14 de noviembre de 1997), 39-58. Barcelona.

GOZALBES FERNÁNDEZ DE PALENCIA, M. (2006): «Las emisiones de la Citerior y su vertiente religiosa», X Curs d'Història monetària d'Hispània. Moneda cultes i ritus (23 i 24 de noviembre de 2006), 111-130. Barcelona.

- (2009): La ceca de Turiazu, Valencia.

GOZALBES GARCÍA, H. (2014): «Las monedas de Segobriga y Ercavica. Un estudio desde la iconografía monetaria», E. Gozalbes, J. A. Hernández y J. A. Almonacid (coords.): Cuenca: La Historia en sus monedas, 129-158. Cuenca.

- (2018): «Hallazgos de moneda provincial hispana procedentes de la ciudad romana de Ercavica (Cañaveruelas, Cuenca)», Lucentum n. XXXVII, 213-232.

- (2019):«El origen de la imagen del toro en la moneda provincial hispana: propaganda religioso-castrense en las emisiones de la Colonia Iulia Victrix Lepida (Velilla del Ebro, Zaragoza) (44-36 aC)», Pyrenae n. 50.2, 29-54.

GRANT, M. (1946): From Imperium to Auctoritas, Cambridge.

- (1950): Aspects of the Principate of Tiberius, New York.

GUADAN, A. M. (1980): La moneda ibérica. Catálogo de numismática ibérica e ibero-romana, Madrid. 
HERNÁNDEZ GUERRA, L. (2006a): «Cascantum», Diccionario Akal de la Antigüedad hispana, 220. Madrid.

- (2006b): «Celsa», Diccionario Akal de la Antigüedad hispana, 241. Madrid.

- (2006c): «Gracchurris», Diccionario Akal de la Antigüedad hispana, 451. Madrid.

- (2006d): «Turiasso», Diccionario Diccionario Akal de la Antigüedad hispana, 937. Madrid.

HURTADO MULLOR, T. (2006): «La imagen y la condición juridical de la ciudad en Hispania. Lépida-Celsa», Moneda, cultes i ritus. X Curs d'Hist'ria monetària d'Hispània (23 i 24 de noviembre de 2006), 87-102. Barcelona.

- (2013): Las emisiones monetarias de la Colonia Victrix Iulia Lepida-Celsa, Tesis doctoral inédita, Universitat de València.

LÓPEZ MONTEAGUDO, G. (1973): «El toro en la numismática ibérica e ibero-romana», Nvmisma n. 120-121, 233-247.

LOSTAL PROS, J. (1980): Arqueología del Aragón romano, Zaragoza.

LLORENS FORCADA, M. M. (2005): «Les emissions llatines de la Hispània Citerior (72-27 a. C)», La moneda al final de la República: entre la tradició i la innovació. IX Curs d'Història monetària d'Hispània (24 i 25 de noviembre de 2005), 115-128, Barcelona.

MACMULLEN, R. (2000): «Spain», Romanization in the Time of Augustus, 50-84. New HavenLondon.

MARTÍN-BUENO, M. (1993): «La ciutat hispano-romana a la vall de l’Ebre», La ciutat hispanoromana, 108-127. Madrid.

MEDRANO MARQUÉS, M. M. y DÍEZ SANZ, M. A. (1985-1986): «Indicios y evidencias de conflictos y cambios políticos en el conventus jurídico caesaraugustano durante la dinastía Julio-Claudia», Kalathos n. 5-6, 161-187.

PÉREZ VILATELA, L. (1990): «La ubicación de Osicerda», El Miliario Extravagante n. 26, 8-9.

RIPOLLÈS, P. P. (1997a): «Las acuñaciones cívicas romanas de la Península Ibérica (44 a. C. -54 d. C.)», C. Alfaro et al. (eds.): Historia monetaria de Hispania antigua, 335-396. Madrid.

- (1997a): «Augusto: las cecas hispanas», La moneda en temps d'August. Curs d'Història monetària d'Hispània (13 i 14 de noviembre de 1997), 21-38. Barcelona.

- (2005): «Las acuñaciones antiguas de la Península Ibérica: dependencias e innovaciones», C. Alfaro, C. Marcos y P. Otero, (eds.): Actas del XIII Congreso Internacional de Numismática (Madrid, 2003), vol. I., 187-208. Madrid.

- (2010): Las acuñaciones provinciales de Hispania, Madrid.

RIPOLLÈS, P. P. y ABASCAL, J. M. (2000): Monedas hispánicas. Real Academia de la Historia, Madrid.

RIPOLLÈS, P. P., BURNETT, A., AMANDRY, M., CARRADICE, I. \& SPOERRI, M. (2015): Roman Provincial Coinage. Consolidated supplement I-III (1992-2015), en red.

RODDAZ, J. M. (1988): «Guerres civiles et romanisation dan la vallée de l’Ebre», Hommages à Robert Etinenne, 317-328. Paris. 
RODEWALD, C. (1979): Money in the age of Tiberius, Manchester.

RUBIO RIVERA, R. (2004): «La ciudad romana de Ercávica», Investigaciones arqueológicas en Castilla La Mancha (1996-2002), 215-228. Toledo.

- (2013): «Los orígenes de Ercávica y su municipalización en el contexto de la romanización de la Celtiberia meridional», Vínculos de Historia n. 2, 169-183.

RUIZ TRAPERO, M. (1956): «Las monedas de Calagoricos-Calagurris en la colección del Museo Arqueológico Nacional», Numario Hispánico, tomoV n. 10.

- (1968): Las acuñaciones hispano-romanas de Calagurris, Barcelona.

SALINAS DE FRÍAS, M. (1986): Conquista y romanización de la Celtiberia, Salamanca.

SANCHO ROCHER, L. (1981): El convento jurídico caesaraugustano, Zaragoza.

SAYAS, J. J. (1996): «Conquista y colonización del valle del Ebro en época tardorepublicana y Principado», Teoría y práctica del ordenamiento municipal en Hispania, 63-82. Vitoria.

SOLANA, J. M. (1989): «Colonización y municipalización bajo César y Augusto: Hispania Citerior», Aspectos de la colonización y municipalización de Hispania, 71-106. Mérida.

- (2006b): «Clunia», Diccionario Akal de la Antigüedad hispana, 269. Madrid.

STYLOW, A. (1995): «Apuntes sobre las "tribus" romanas en Hispania», Veleia. Revista de prehistoria, historia antigua, arqueología y filología clásicas n. 12, 105-124.

- (1969): «En torno al uso en época imperial de los mismos cuños de anverso por distintas ciudades», Gaceta Numismática n. . 12, 21-22.

VILLARONGA, L. (1994): Corpos Nvmmorom Hispaniae ante Avgusti Aetate, Madrid. (citado como $\mathrm{CNH})$.

- (2004): Numismàtica antiga de la Península Ibèrica, Barcelona.

VILLARONGA, L. y BENAGES, J. (2011): Ancient coinage of the Iberian Peninsula, Barcelona.

WIEGELS, R. (1985): Die Tribusinschriften des römischen Hispanien. Ein Katalog, Berlin. 